\title{
Interaction of zinc and IAA alleviate aluminum-induced damage on photosystems via promoting proton motive force and reducing proton gradient in alfalfa
}

\author{
Liantai Su', Jianping Xie ${ }^{1}$, Wuwu Wen ${ }^{1}$, Jiaojiao $\mathrm{Li}^{1}$, Peng Zhou ${ }^{1}$ and Yuan $\mathrm{An}^{1,2^{*}}$ (D)
}

\begin{abstract}
Background: In acidic soils, aluminum (Al) competing with Zn results in Zn deficiency in plants. Zn is essential for auxin biosynthesis. Zn-mediated alleviation of Al toxicity has been rarely studied, the mechanism of Zn alleviation on Al-induced photoinhibition in photosystems remains unclear. The objective of this study was to investigate the effects of $\mathrm{Zn}$ and IAA on photosystems of Al-stressed alfalfa. Alfalfa seedlings with or without apical buds were exposed to 0 or $100 \mu \mathrm{M} \mathrm{AlCl}_{3}$ combined with 0 or $50 \mu \mathrm{M} \mathrm{ZnCl}_{2}$, and then foliar spray with water or $6 \mathrm{mg} \mathrm{L}^{-1}$ IAA.

Results: Our results showed that Al stress significantly decreased plant growth rate, net photosynthetic rate (Pn), quantum yields and electron transfer rates of PSI and PSII. Exogenous application of Zn and IAA significantly alleviated the Al-induced negative effects on photosynthetic machinery, and an interaction of Zn and IAA played an important role in the alleviative effects. After removing apical buds of Al-stressed alfalfa seedlings, the values of pmf, $\mathrm{gH}^{+}$and $\mathrm{Y}(\mathrm{II})$ under exogenous spraying IAA were significantly higher, and $\Delta \mathrm{pH}_{p m f}$ was significantly lower in $\mathrm{Zn}$ addition than Al treatment alone, but the changes did not occur under none spraying IAA. The interaction of $\mathrm{Zn}$ and IAA directly increased $Y(I), Y(I I), E T R I$ and ETRII, and decreased $\mathrm{O}_{2}^{-}$content of Al-stressed seedlings. In addition, the transcriptome analysis showed that fourteen functionally noted genes classified into functional category of energy production and conversion were differentially expressed in leaves of alfalfa seedlings with and without apical buds.
\end{abstract}

Conclusion: Our results suggest that the interaction of zinc and IAA alleviate aluminum-induced damage on photosystems via increasing $\mathrm{pmf}$ and decreasing $\Delta \mathrm{pH}_{\text {pmf }}$ between lumen and stroma.

Keywords: Aluminum, Cyclic electron flow, IAA, Zinc, Proton motive force, Proton gradient

\footnotetext{
* Correspondence: anyuan@sjtu.edu.cn

'School of Agriculture and Biology, Shanghai Jiao Tong University, Shanghai 200240, People's Republic of China

${ }^{2}$ Key Laboratory of Urban Agriculture, Ministry of Agriculture, Shanghai

201101, China
}

(c) The Author(s). 2020 Open Access This article is licensed under a Creative Commons Attribution 4.0 International License, which permits use, sharing, adaptation, distribution and reproduction in any medium or format, as long as you give appropriate credit to the original author(s) and the source, provide a link to the Creative Commons licence, and indicate if changes were made. The images or other third party material in this article are included in the article's Creative Commons licence, unless indicated otherwise in a credit line to the material. If material is not included in the article's Creative Commons licence and your intended use is not permitted by statutory regulation or exceeds the permitted use, you will need to obtain permission directly from the copyright holder. To view a copy of this licence, visit http://creativecommons.org/licenses/by/4.0/ The Creative Commons Public Domain Dedication waiver (http://creativecommons.org/publicdomain/zero/1.0/) applies to the data made available in this article, unless otherwise stated in a credit line to the data. 


\section{Background}

Aluminum toxicity is a major factor limiting crop production in acid soils [1]. The inhibition of photosynthetic apparatus, including light-harvesting photosystem II (PSII), photosystem I (PSI) and cytochrome $\mathrm{b}_{6} \mathrm{f}$, is an important reason for the crop production limitation. PSII has three functional domains: antenna of chlorophyll (Chl), reaction center (RC) and oxygen evolving complex (OEC). The antenna absorbs and transfers photon energy to the reaction center where the excited state electrons from Chl a molecules (P680) and the OEC are transferred to a series of electron acceptors [2]. PSI catalyzes the light-driven electron transfer from plastocyanin to ferredoxin located in the stromal side [3]. The electron transport from PSII to PSI is tightly coupled with the generation of the thylakoid proton motive force $(p m f)$, which consist of electric field $(\Delta \Psi)$ and $\mathrm{pH}(\Delta \mathrm{pH})$ gradients between lumen and stroma, and is the driving force for ATP synthesis in plants [4, 5]. It has been shown that $\mathrm{Al}$ stress could closure reaction centers (RCs) of PSII and PSI, impair light harvesting complex antennas of PSII (LHCII) and PSI (LHCI), reduce energy transfer from antennas to RCs, and inhibit electron transfer on the acceptor sides of PSI [4, 6]. These effects directly contribute to the reduction of net photosynthetic rate and plant growth under $\mathrm{Al}$ stress.

Zinc is an essential nutrient for plants, not only as a catalytic factor in enzymes, but also as a necessary structural component of proteins [7]. Zn normally presents in a high level in plants, and exerts as a cofactor of over 300 enzymes. A whole genome survey shows that $4-10 \%$ of all sequenced proteins from prokaryotes and eukaryotes contain Zn-binding domains [8]. Zn plays an important role in decreasing the harmful effects of abiotic stresses through scavenging ROS, retaining heavy metal in roots and keeping heavy metal concentration in mesophyll cells in non-toxic forms [9-13]. These damage symptoms initially appear in young leaves and meristems of plants due to the low mobility of $\mathrm{Zn} \mathrm{[14].} \mathrm{Zn}$ deficiency has been one of the most widespread micronutrient constraints in plants.

Auxin is one major hormone involved in plant adaptation to abiotic stresses. Singh and Prasad [15] reported that IAA improved photosynthetic efficiency of Cd-treated seedlings by restoring functional and structural attributes of photochemistry system. Al stress inhibits the IAA synthesis in alfalfa (Medicago sativa $\mathrm{L}$ ), but this inhibition can be alleviated by $\mathrm{Zn}$ addition [16] due to zinc participating the IAA synthesis [17]. Thus, the poor photosynthetic performance due to $\mathrm{Zn}$ deficiency under $\mathrm{Al}$ stress may relate to the decrease of IAA synthesis. However, how auxin and $\mathrm{Zn}$ affecting $\mathrm{Al}$-induced inhibition of photosynthetic efficiency is barely known.
$\mathrm{Zn}$ availability in acidic soils is generally high, thus, it easily leaches from acidic soil, and its absorption intensively antagonizes by other cations such as $\mathrm{Al}$, ammonium and potassium. In acidic soils, $\mathrm{Al}$ competes with $\mathrm{Zn}$ to bind in its binding sites on plasma membrane of roots, consequently interferes with $\mathrm{Zn}$ uptake and causes $\mathrm{Zn}$ deficiency in plants [18]. Thus, plants often suffer from Zn deficiency in acidic soils. Lin et al. [19] reported that the presence of $\mathrm{Zn}$ at physiological concentrations could protect the cells by preventing the $\mathrm{Al}$-induced superoxide generation in rice and tobacco. To our knowledge, $\mathrm{Zn}$-mediated alleviation of $\mathrm{Al}$ toxicity is rarely studied, and the mechanism of $\mathrm{Zn}$ alleviating $\mathrm{Al}$ induced photoinhibition in photosystems remains unclear. Because Zn participates in IAA synthesis, and both of $\mathrm{Zn}$ and IAA have the function of alleviating plant Al toxicity in acidic soils, we speculated that an interaction of $\mathrm{Zn}$ and IAA might occur in plants to affect photosynthetic apparatus under Al stress. Thus, we focused on studying the effects of Zn, IAA and their interaction on photosystems of plants under $\mathrm{Al}$ stress using alfalfa (Medicago sativa L.) as plant materials.

\section{Results \\ IAA contents in shoots}

IAA content in shoots was $37.0 \%$ lower in $\mathrm{Al}$ treatment than in control treatment, but addition of $25 \mu \mathrm{M}$ or $50 \mu \mathrm{M} \mathrm{Zn}$ significantly increased IAA contents by 50.7 and $62.2 \%$, respectively, in comparison with excess $\mathrm{Al}$ treatment (Fig.1a).

\section{Plant growth}

Al stress significantly decreased fresh weights of roots (Fig.1b) and shoots (Fig. 1c), as well as root length (Additional file 1: Figure S1) compared with control treatment. The $\mathrm{Al}$-induced growth inhibition was significantly alleviated after $\mathrm{Zn}$ and IAA applications either alone or combination, and the weights were significantly higher in the combined application of $\mathrm{Zn}$ and IAA than $\mathrm{Zn}$ or IAA application alone. There were no significant difference of root weights and shoot weights, separately, at 3rd and 6rd days after application of $\mathrm{Zn}$ and IAA under $\mathrm{Al}$ stress. Thus, the seedlings at $3 \mathrm{rd}$ day were mainly selected for the following study.

\section{Contents of $\mathrm{Al}$ and $\mathrm{Zn}$ in roots and shoots}

$\mathrm{Zn}$ addition decreased $\mathrm{Al}$ contents in roots (Additional file 2: Figure S2a) and shoots (Additional file 2: Figure S2b) compared with $\mathrm{Al}$ treatment alone. Combined application of $\mathrm{Zn}$ and IAA further decreased $\mathrm{Al}$ contents in roots compared with $\mathrm{Zn}$ addition alone, but there was no significant difference in shoots between $\mathrm{Zn}$ application with or without IAA. Application of IAA alone increased $\mathrm{Al}$ contents in roots compared with $\mathrm{Al}$ 

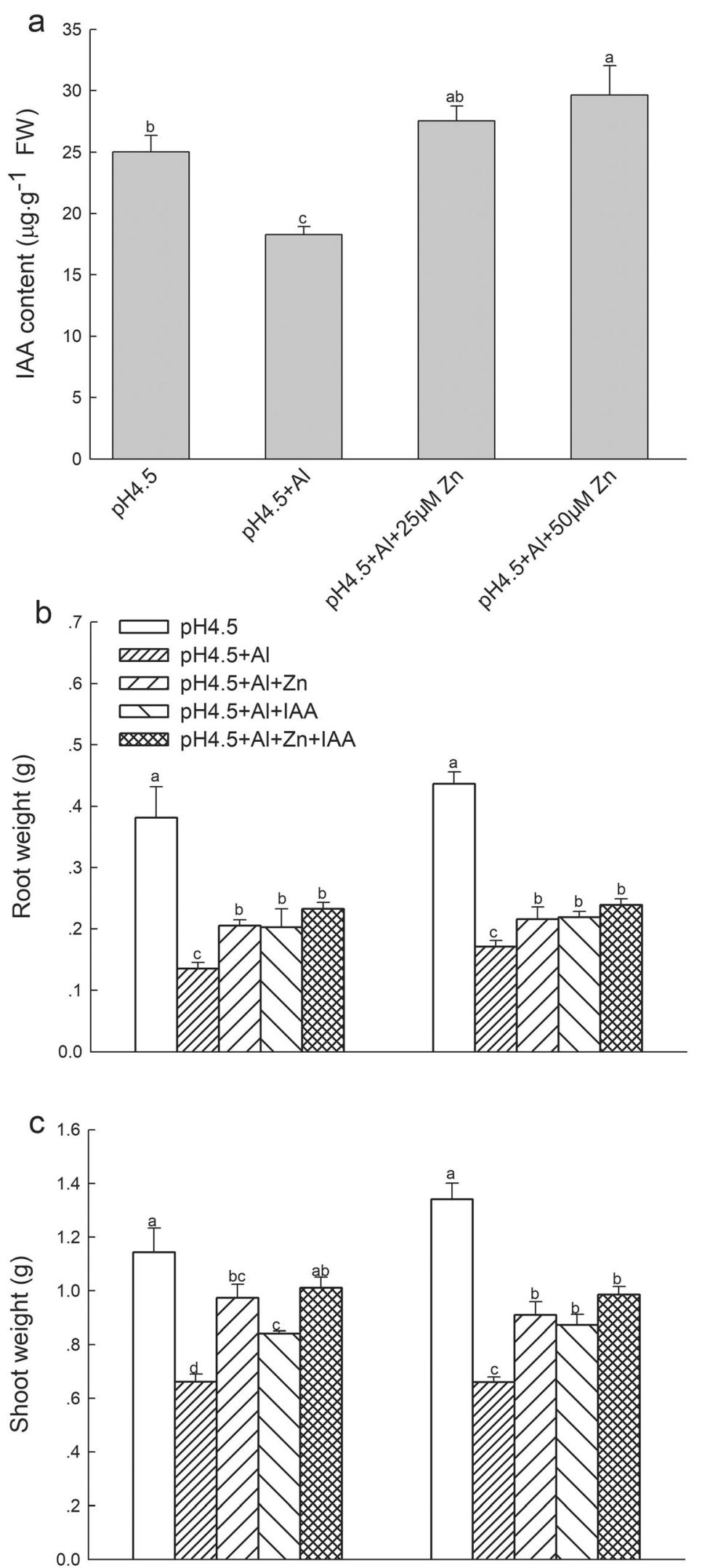

$3 d$

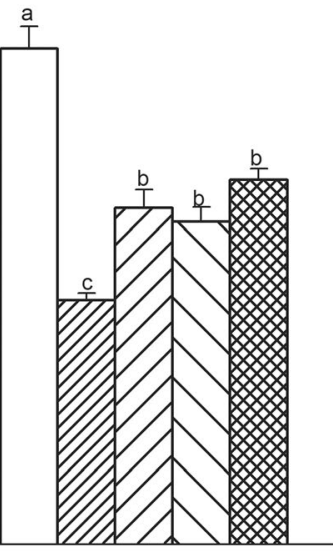

$6 \mathrm{~d}$

Fig. 1 (See legend on next page.) 
(See figure on previous page.)

Fig. $1 \mathrm{IAA}$ contents in shoots (a) of alfalfa seedlings with apical buds grown in $1.5 \mathrm{mM} \mathrm{Ca}\left(\mathrm{NO}_{3}\right)_{2}$ medium ( $\left.\mathrm{pH} 4.5\right)$ containing $0 \mu \mathrm{M} \mathrm{AlCl} 3$ ( $\mathrm{pH} 4.5$ ),

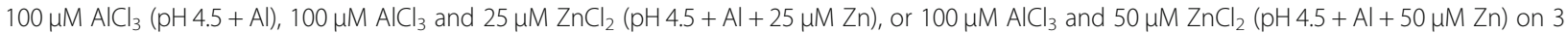
d. Fresh weights of root (b) and shoot (c) of alfalfa seedlings grown in $1.5 \mathrm{mM} \mathrm{Ca}\left(\mathrm{NO}_{3}\right)_{2}$ mediums $(\mathrm{pH} 4.5)$ containing $0 \mu \mathrm{M} \mathrm{AlCl} 3(\mathrm{pH} 4.5), 100 \mu \mathrm{M}$ $\mathrm{AlCl}_{3}(\mathrm{pH} 4.5+\mathrm{Al}), 100 \mu \mathrm{M} \mathrm{AlCl}$ and $50 \mu \mathrm{M} \mathrm{ZnCl} 2(\mathrm{pH} 4.5+\mathrm{Al}+\mathrm{Zn}), 100 \mu \mathrm{M} \mathrm{AlCl}_{3}$ and $6 \mathrm{mg} \mathrm{L}^{-1}$ IAA (foliar spray) (pH $\left.4.5+\mathrm{Al}+\mathrm{IAA}\right)$ or $100 \mu \mathrm{M}$ $\mathrm{AlCl}_{3}$ and $50 \mu \mathrm{M} \mathrm{ZnCl}$ and $6 \mathrm{mg} \mathrm{L}^{-1} \mathrm{IAA}$ (foliar spray) $(\mathrm{pH} 4.5+\mathrm{Al}+\mathrm{Zn}+\mathrm{IAA})$. Data are means \pm SE of three replicates from three independent experiments. Bars with different letters indicate significant difference at $P<0.05$ (Leas significant difference test)

treatment alone, but there was no significant difference in shoots.

$\mathrm{Zn}$ contents in roots (Additional file 2: Figure S2c) and shoots (Additional file 2: Figure S2d) were significantly higher in combined application of $\mathrm{Zn}$ and IAA than $\mathrm{Zn}$ addition under $\mathrm{Al}$ stress. The ratio of $\mathrm{Al} / \mathrm{Zn}$ in roots and shoots was 7.88 and 0.63 in $\mathrm{Zn}$ addition, and 5.34 and 0.42 in combined application of $\mathrm{Zn}$ and IAA under $\mathrm{Al}$ stress, respectively (Additional file 2: Figure S2e, f). A lower $\mathrm{Al} / \mathrm{Zn}$ ratio in combined application of $\mathrm{Zn}$ and IAA indicates that the interaction of $\mathrm{Zn}$ and IAA maintains $\mathrm{Al} / \mathrm{Zn}$ homeostasis under $\mathrm{Al}$ stress condition.

\section{Photosynthetic rates, RuBisCO activities and carbonic anhydrase activities}

Net photosynthetic rates (Pn) of alfalfa seedlings significantly decreased under $\mathrm{Al}$ stress compared with control treatment, but application of $\mathrm{Zn}$ and IAA either alone or combination significantly increased the Pn compared with $\mathrm{Al}$ treatment alone. The Pn was lower in IAA application alone than $\mathrm{Zn}$ application with or without IAA (Fig.2a). Al stress significantly decreased foliar RuBisCO activity (Fig.2b) and foliar carbonic anhydrase activity (Fig.2c) in comparison with control treatment, while application of $\mathrm{Zn}$ and IAA either alone or combination significantly increased the two enzyme activities compared with $\mathrm{Al}$ treatment alone.

\section{Chlorophyll fluorescence parameters of PSI and PSII}

$\mathrm{Al}$ stress significantly decreased effective quantum yields of PSI $[\mathrm{Y}(\mathrm{I})]$ and PSII [Y(II)] compared with control treatment, while application of IAA and $\mathrm{Zn}$ in combination significantly increased the $\mathrm{Y}$ (I) (Fig.3a) and Y(II) (Fig.3b) compared with $\mathrm{Al}$ treatment alone. The $\mathrm{Y}(\mathrm{ND})$, $\mathrm{Y}(\mathrm{NA}), \mathrm{Y}(\mathrm{NPQ})$ and $\mathrm{Y}(\mathrm{NO})$ were shown in Additional file 3: Figure S3a-d.

After removing apical buds of alfalfa seedlings, $\mathrm{Al}$ stress significantly decreased the $\mathrm{Y}(\mathrm{I})$ (Fig.3c) and $\mathrm{Y}(\mathrm{II})$ (Fig.3d) under none spraying IAA compared with control treatment. $\mathrm{Zn}$ addition significantly increased $\mathrm{Y}(\mathrm{I})$ under none spraying IAA and $\mathrm{Y}(\mathrm{II})$ under spraying IAA compared with Al treatment. Both Y(I) and Y(II) were higher under spraying IAA than none spraying IAA under $\mathrm{Al}$ stress. The $\mathrm{Y}(\mathrm{ND}), \mathrm{Y}(\mathrm{NA}), \mathrm{Y}(\mathrm{NPQ})$ and $\mathrm{Y}(\mathrm{NO})$ were shown in Additional file 3: Figure S3e-h.
The number and area of yellow-green spot in leaves of seedlings with apical buds were larger in Al treatment alone than $\mathrm{Zn}$ and IAA addition either alone or combination, indicating that $\mathrm{Al}$ stress decreased maximum quantum yield of primary photochemistry (Fv/Fm). Application of $\mathrm{Zn}$ and IAA greatly alleviated $\mathrm{Al}$ induced damage on primary photochemistry (Additional file 4: Figure S4).

\section{Light intensity dependence of photosynthetic electron transport rates in PSI and PSII}

$\mathrm{Al}$ stress strongly inhibited ETRI and ETRII, and their initial slopes of curves were lowest among all treatments (Fig.4). Applications of $\mathrm{Zn}$ and IAA either alone or combination alleviated the Al-induced decreases of ETRI (Fig.4a) and ETRII (Fig.4b), and the ETRI and ETRII were higher in combined application of $\mathrm{Zn}$ and IAA than $\mathrm{Zn}$ or IAA application alone.

Application of $\mathrm{Zn}$ and IAA either alone or combination greatly increased the initial slopes of $\mathrm{P} 700^{+}$reduction curves compared with $\mathrm{Al}$ treatment alone, which means that the releasing rate of electrons from oxidized P700 was increased by $\mathrm{Zn}$ and IAA addition, and the releasing rate was higher in the combined application of $\mathrm{Zn}$ and IAA than $\mathrm{Zn}$ or IAA application alone (Fig.4c).

After removing apical buds of alfalfa seedlings, Al stress greatly inhibited ETRI (Fig.4d) and ETRII (Fig.4e) under both spray and none spray of IAA. Zn addition with or without spray IAA greatly increased the ETRI and ETRII of Al-stressed seedlings, with higher increases of ETRI and ETRII under spraying IAA. The initial slopes of the $\mathrm{P} 700^{+}$reduction curves were higher under spraying IAA than none spraying IAA, and the highest initial slope occurred in $\mathrm{Zn}$ treatment with spraying IAA among the six treatments (Fig.4f).

The minimum saturating irradiances $\left(\mathrm{I}_{k}\right)$ of PSI and PSII were significantly decreased by $\mathrm{Al}$ stress, and $\mathrm{Zn}$ and IAA addition either alone or combination significantly increased $\mathrm{I}_{k}$ of PSI (Additional file 5: Figure S5a) and PSII (Additional file 5: Figure S5b) compared with $\mathrm{Al}$ stress.

\section{Cyclic electron flow}

The light response change of cyclic electron flow (CEF) around PSI was decreased after exposure to excess $\mathrm{Al}$ in comparison with control, but application of $\mathrm{Zn}$ and IAA 

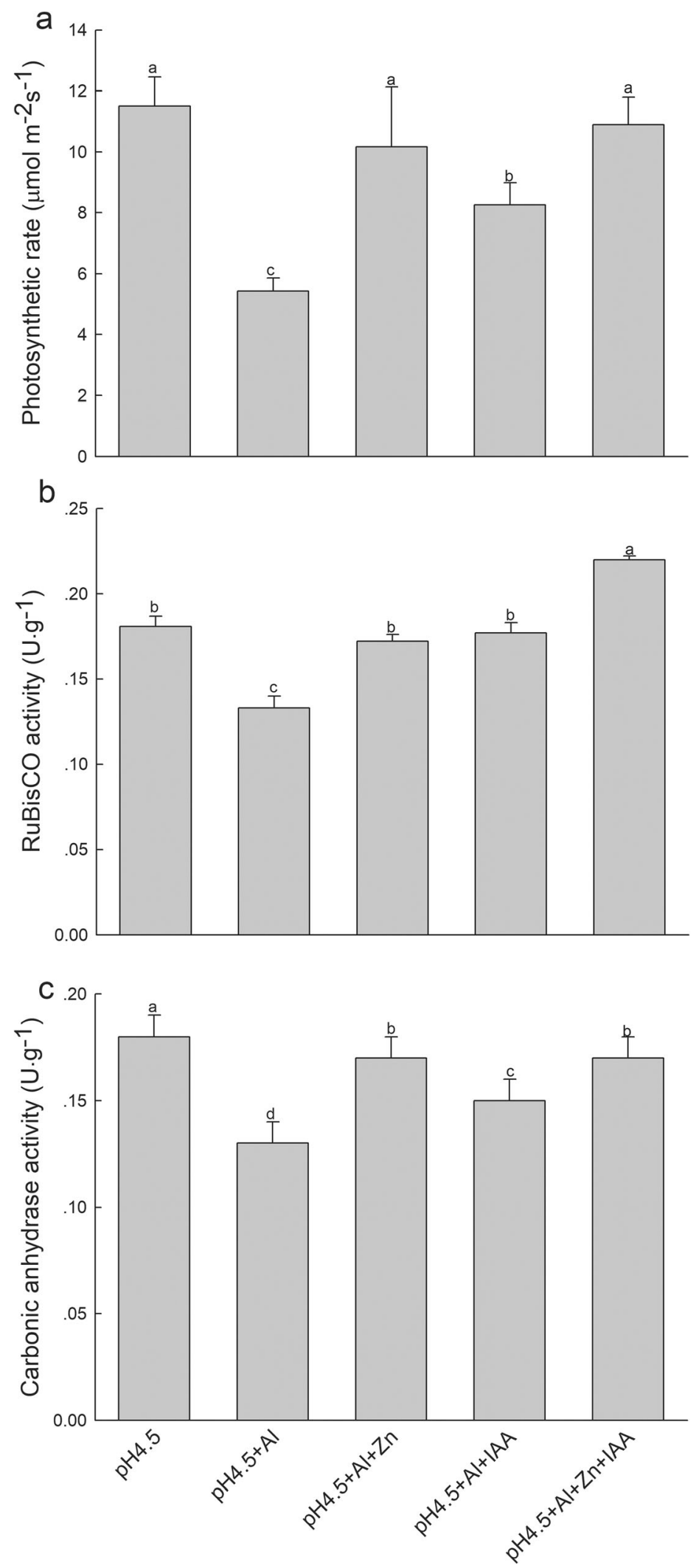

Fig. 2 (See legend on next page.) 
(See figure on previous page.)

Fig. 2 Net photosynthetic rate (a), RuBisCO activities (b) and carbonic anhydrase activities (c) in leaves of alfalfa seedlings with apical buds grown in $1.5 \mathrm{mM} \mathrm{Ca}\left(\mathrm{NO}_{3}\right)_{2}$ medium ( $\mathrm{pH}$ 4.5) containing $0 \mu \mathrm{M} \mathrm{AlCl} 3(\mathrm{pH} 4.5), 100 \mu \mathrm{M} \mathrm{AlCl} 3(\mathrm{pH} 4.5+\mathrm{Al}), 100 \mu \mathrm{M} \mathrm{AlCl}$ and $50 \mu \mathrm{M} \mathrm{ZnCl} 2(\mathrm{pH} 4.5+\mathrm{Al}+\mathrm{Zn})$, $100 \mu \mathrm{M} \mathrm{AlCl}_{3}$ and $6 \mathrm{mg} \mathrm{L}^{-1}$ IAA (foliar spray) (pH $4.5+\mathrm{Al}+\mathrm{IAA}$ ) or $100 \mu \mathrm{M} \mathrm{AlCl}$ and $50 \mu \mathrm{M} \mathrm{ZnCl}_{2}$ and $6 \mathrm{mg} \mathrm{L}^{-1}$ IAA (foliar spray) (pH $4.5+\mathrm{Al}+$ $\mathrm{Zn}+(\mathrm{AA})$ on 3 days. Data are means \pm SE of three replicates from three independent experiments. Bars with different letters indicate significant difference at $P<0.05$ (Leas significant difference test)

either alone or combination greatly increased CEF under excess $\mathrm{Al}$, and the highest increase was under the combined treatment of $\mathrm{Zn}$ and IAA (Fig.5a).

\section{Proton motive force and thylakoid proton conductivity} At light intensities of $582 \mu \mathrm{mol}$ photons $\mathrm{m}^{-2} \mathrm{~s}^{-1}$, the total proton motive force (pmf) (Fig.5b) and proton conductivity $\left(\mathrm{g}_{\mathrm{H}}^{+}\right.$) (Fig.5c) in thylakoid membrane significantly decreased under $\mathrm{Al}$ stress compared with control treatments. Application of $\mathrm{Zn}$ and IAA either alone or combination significantly alleviated the negative effects, and increased their $p m f$ and $\mathrm{g}_{\mathrm{H}}{ }^{+}$under $\mathrm{Al}$ stress. Both of $p m f$ and $\mathrm{g}_{\mathrm{H}}{ }^{+}$were higher in the combined application of $\mathrm{Zn}$ and IAA than $\mathrm{Zn}$ or IAA application alone.
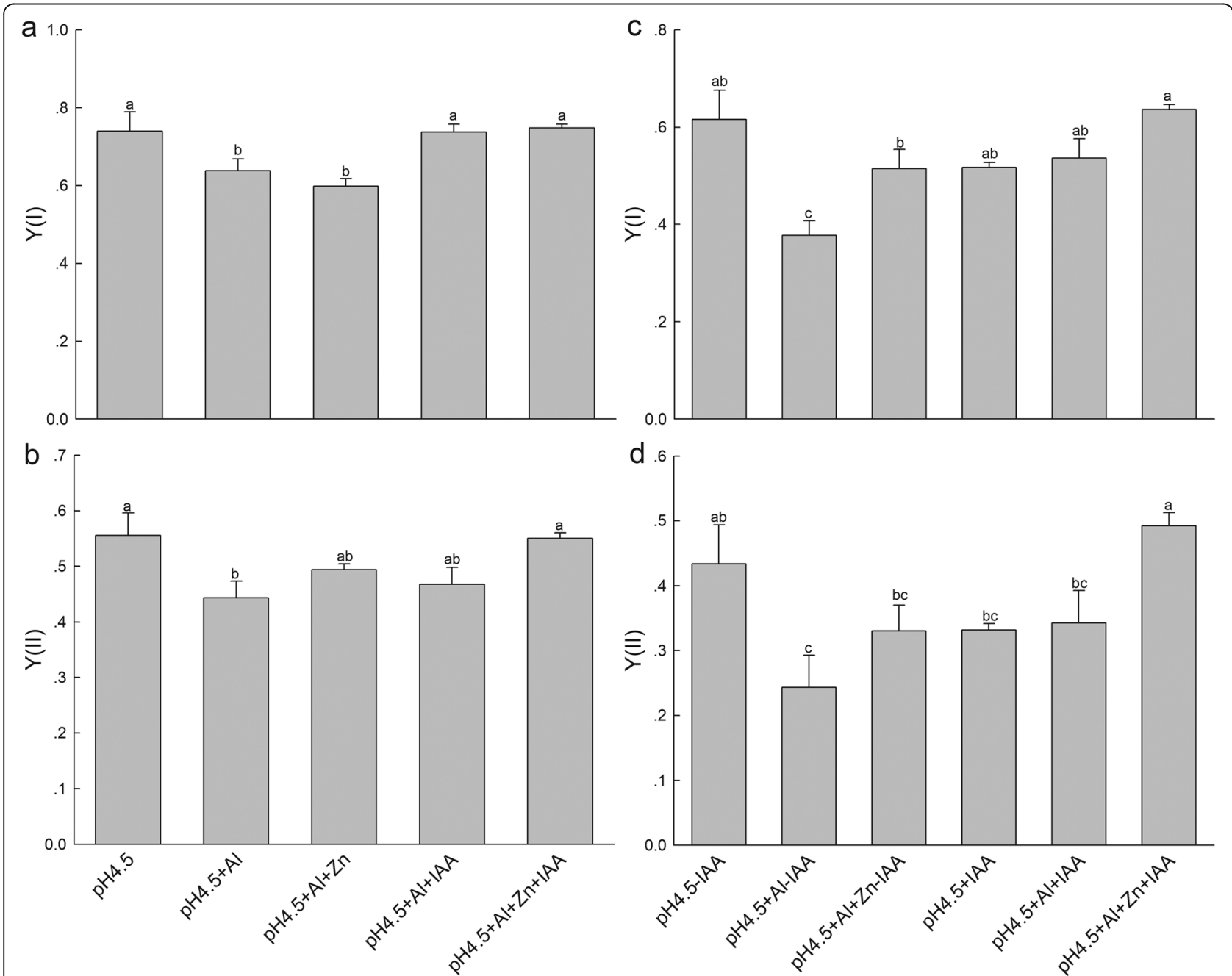

Fig. 3 Light intensity dependence of photosynthetic quantum yields of PSI $[Y(I)]$ and PSII $[(Y(I)]$ in leaves of alfalfa seedlings with or without apical buds. Five treatments in the seedlings with apical buds are as Fig.2, and seedlings without apical buds are grown in $1.5 \mathrm{mM} \mathrm{Ca}\left(\mathrm{NO}_{3}\right)_{2}$ medium ( $\mathrm{pH} 4.5$ ) and treated with or without spraying IAA (pH 4.5-IAA, pH 4.5 + IAA), $100 \mu \mathrm{M} \mathrm{AlCl}$ with or without spraying IAA (pH 4.5 + Al-IAA, $\mathrm{pH} 4.5+\mathrm{Al}+\mathrm{IAA})$ and $100 \mu \mathrm{M} \mathrm{AlCl}$ and $50 \mu \mathrm{M} \mathrm{ZnCl}$ with or without spraying IAA (pH $4.5+\mathrm{Al}+\mathrm{Zn}-\mathrm{IAA}, \mathrm{pH} 4.5+\mathrm{Al}+\mathrm{Zn}+\mathrm{IAA})$. The Y(I) (a) and $Y(I I)(\mathbf{b})$ were estimated from seedlings with apical buds, and $Y(I)$ (c) and $Y(I I)$ (d) were estimated from seedlings without apical buds on day 3. At least 6 different leaves from different seedlings were used for each treatment and data are means \pm SE of three replicates. Bars with different letters indicate significant difference at $P<0.05$ (Leas significant difference test) 


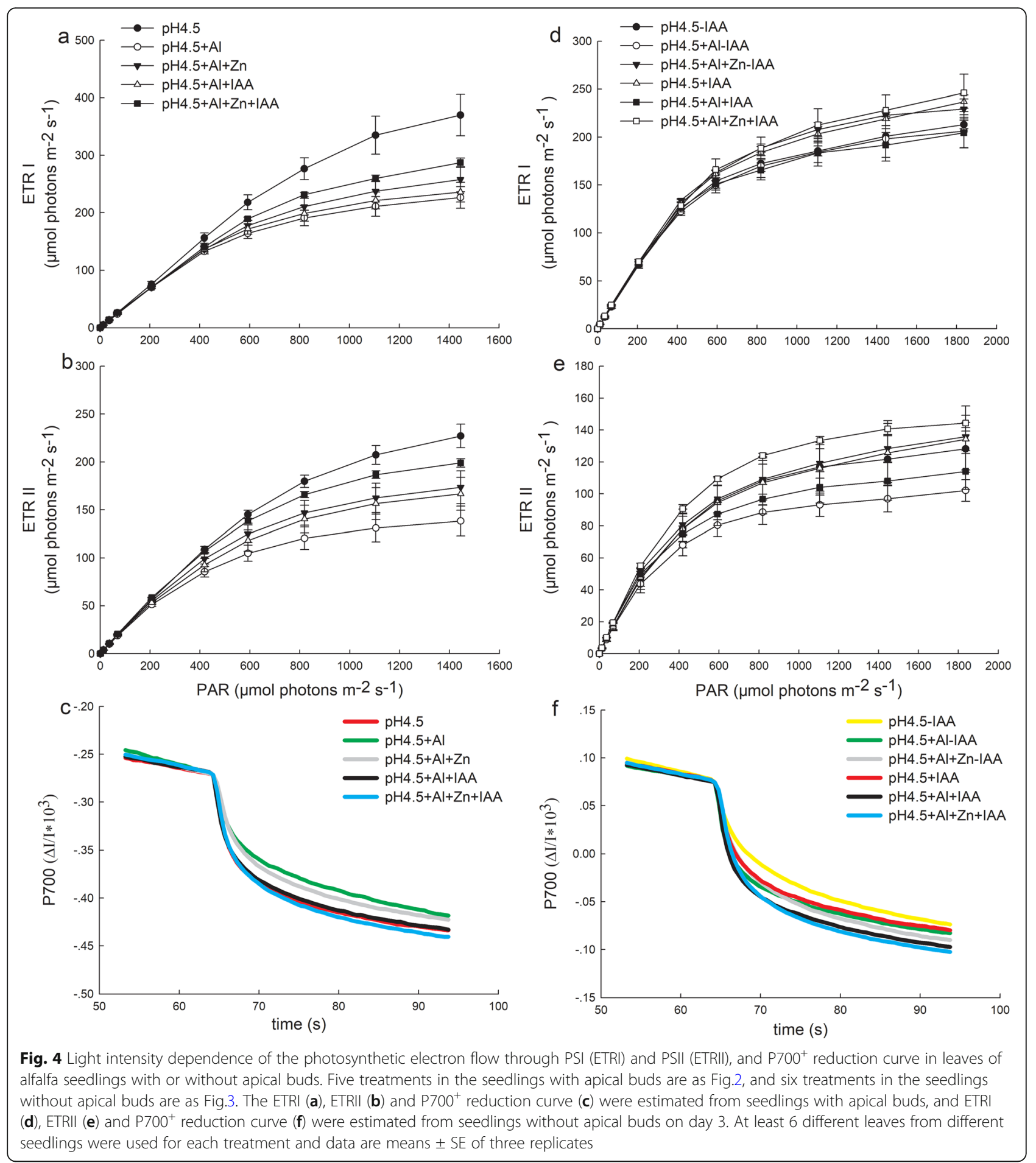

Excess $\mathrm{Al}$ significantly increased $\Delta \mathrm{pH}_{p m f}$ compared with control treatment, but application of $\mathrm{Zn}$ and IAA either alone or combination reduced the $\Delta \mathrm{pH}_{p m f}$ compared with $\mathrm{Al}$ treatment alone (Fig.5d).

After removing apical buds of alfalfa seedlings, $\mathrm{Al}$ stress significantly decreased pmf (Fig.5e), but did not affect $\mathrm{g}_{\mathrm{H}}{ }^{+}$(Fig.5f) and $\Delta \mathrm{pH}_{p m f}$ (Fig.5g) compared with control treatment under none spraying IAA. Meanwhile, $\mathrm{Zn}$ addition did not affect the $p m f, \mathrm{~g}_{\mathrm{H}}{ }^{+}$and $\Delta \mathrm{pH}_{p m f}$ compared with $\mathrm{Al}$ treatment. Under condition of spraying IAA, $\mathrm{Al}$ stress significantly decreased $\mathrm{g}_{\mathrm{H}}{ }^{+}$ compared with control treatment, but $\mathrm{Zn}$ addition increased $p m f$ and decreased $\Delta \mathrm{pH}_{p m f}$ compared with $\mathrm{Al}$ treatment. The values of $p m f$ and $\mathrm{g}_{\mathrm{H}}{ }^{+}$under $\mathrm{Al}$ stress 

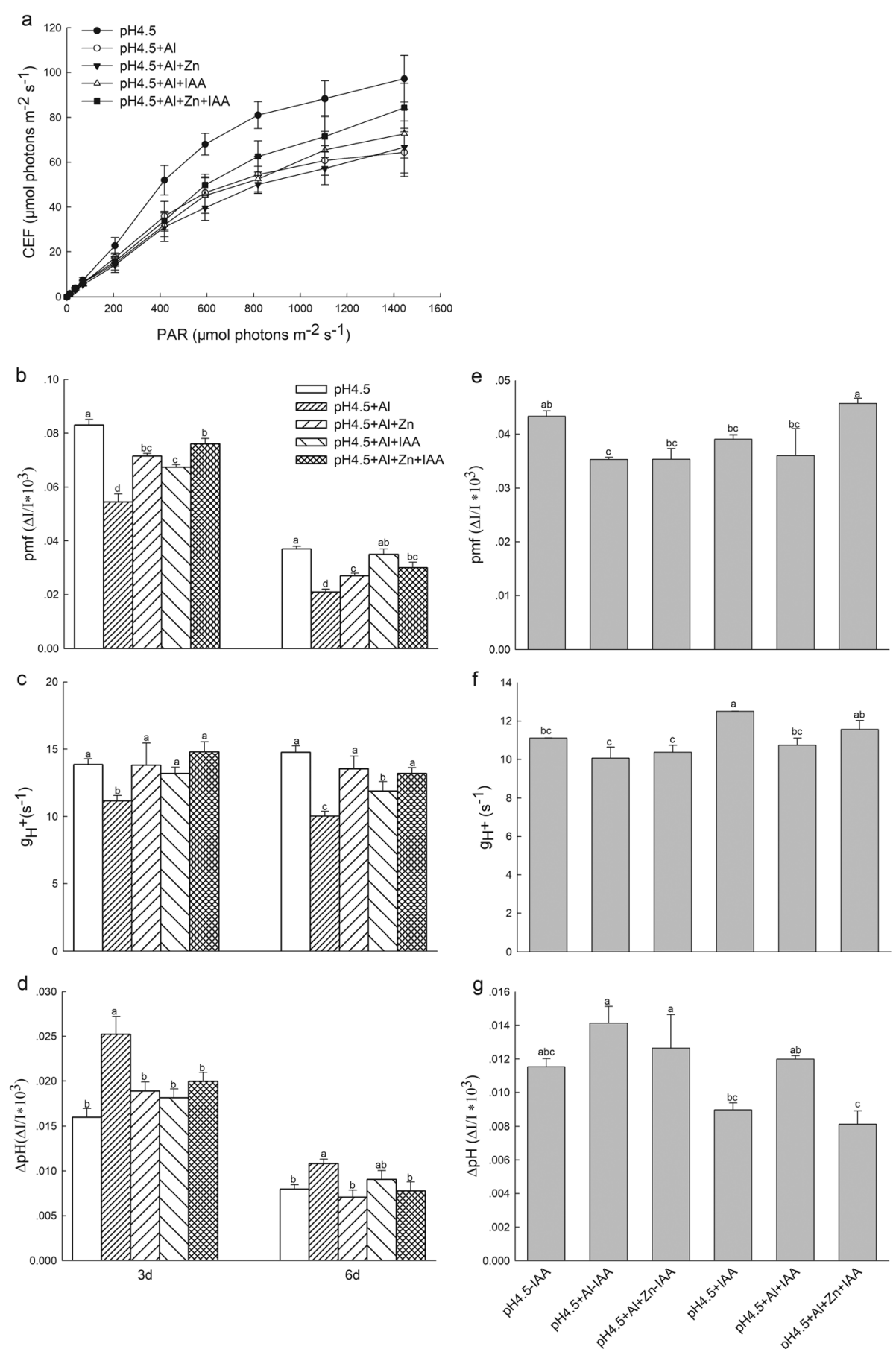

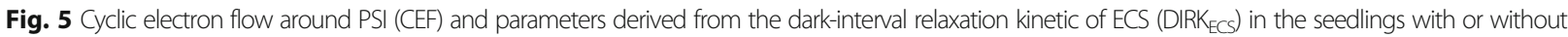
apical buds. Five treatments in the seedlings with apical buds are as Fig.2, and six treatments in the seedlings without apical buds are as Fig.3. CEF (a), total proton motive force $(\mathrm{pmf})(\mathbf{b})$, the proton gradient $(\Delta \mathrm{pH})(\mathbf{c})$ and the thylakoid proton conductivity $\left(\mathrm{g}_{{ }^{+}}{ }^{+}\right)(\mathbf{d})$ were estimated from seedlings with apical buds, and $\operatorname{pmf}(\mathbf{e}), \Delta \mathrm{pH}(\mathbf{f})$ and $\mathrm{g}_{H}{ }^{+}(\mathbf{g})$ were estimated from seedlings without apical buds. At least 6 different leaves from different seedlings were used for each treatment and data are means of three replicates. Bars with different letters indicate significant difference at $P<0.05$ (Leas significant difference test)

either alone or combination with $\mathrm{Zn}$ were lower under none spraying IAA than spraying IAA, while $\Delta \mathrm{pH}_{p m f}$ was higher under none spraying IAA than spraying IAA.
Activation state of ATP synthase and $\mathrm{H}^{+}$-ATPase activity Changes in P515 signals reflect the activation state of ATP synthase located in thylakoid membrane [20]. The initial slop of P515 curve is positive to the activation 
state of the ATP synthase. The ATP synthase activities were lowest in excess $\mathrm{Al}$ treatment alone, and highest in the combined treatment of $\mathrm{Zn}$ and IAA (Fig.6a). After removing apical buds of alfalfa seedlings, the ATP synthase activities were higher under spraying IAA than none spraying IAA (Fig.6b). The combined application of Zn and IAA had highest ATP synthase activities among all treatments.

Excess of Al significantly decreased foliar $\mathrm{H}^{+}$-ATPase activity in comparison with control treatment, while application of $\mathrm{Zn}$ and IAA either alone or combination significantly increased $\mathrm{H}^{+}$-ATPase activities in $\mathrm{Al}$ stressed alfalfa seedlings, and IAA application with or without $\mathrm{Zn}$ addition had higher $\mathrm{H}^{+}$-ATPase activities than $\mathrm{Zn}$ treatment alone (Fig.6c).

\section{Contents of $\mathrm{NADP}^{+}, \mathrm{NADPH}$ and $\mathrm{O}_{2}^{-}$}

After removing apical buds, $\mathrm{NADP}^{+}$contents significantly decreased under none spraying IAA, but increased under spraying IAA compared with control treatments in the presence of $\mathrm{Al}$. $\mathrm{Zn}$ addition increased $\mathrm{NADP}^{+}$ contents of Al-stressed seedlings either with or without introduction of IAA (Fig.6d). NADPH contents significantly decreased under both with or without introduction of IAA in the presence of $\mathrm{Al}$, while $\mathrm{Zn}$ addition significantly increased NADPH content of Al-stressed seedlings under none spraying IAA (Fig.6e). Al stress increased $\mathrm{O}_{2}{ }^{-}$contents compared with control treatments, but significantly decreased by $\mathrm{Zn}$ addition comparted with $\mathrm{Al}$ treatments under both with or without introduction of IAA (Fig.6f).
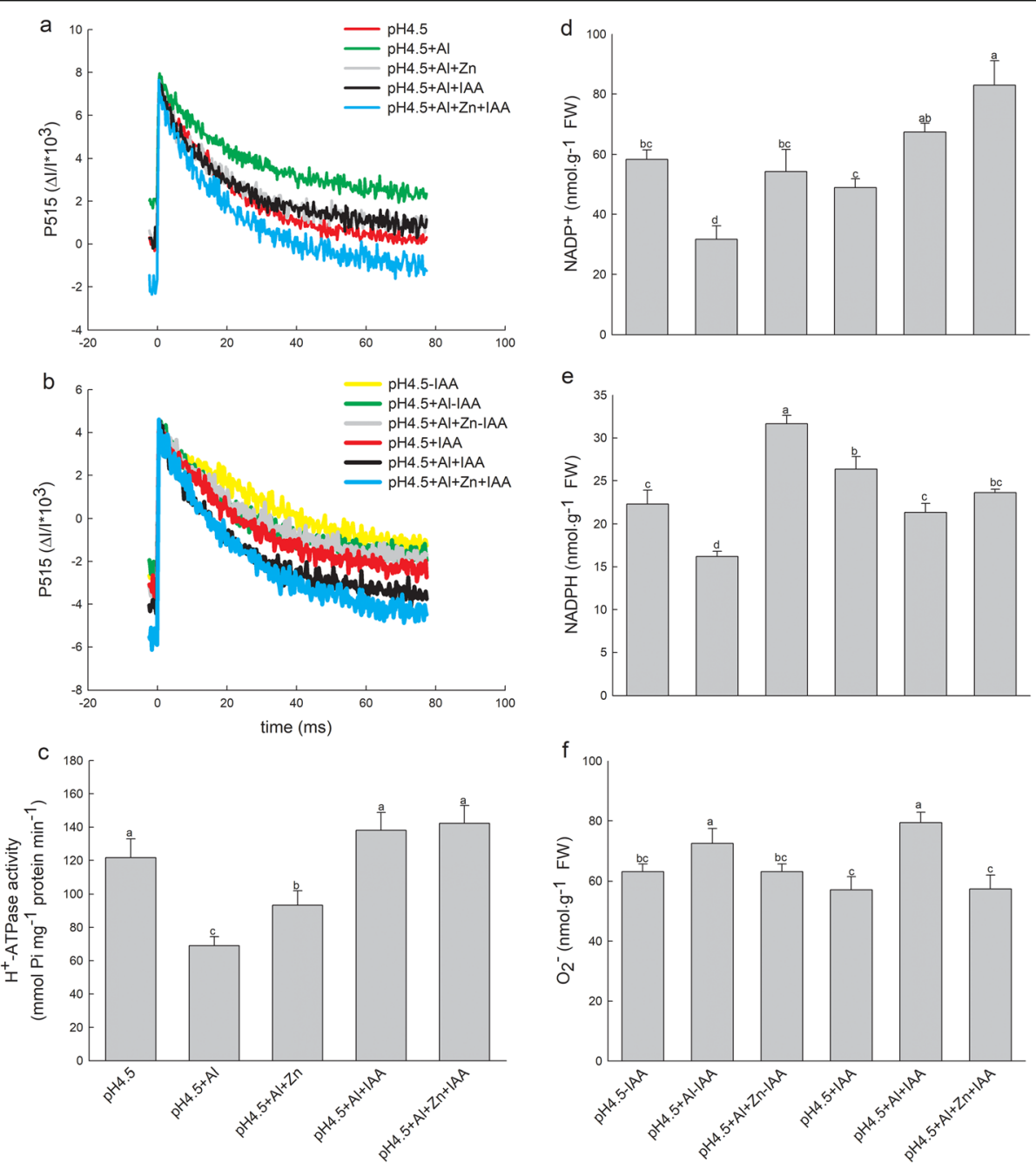

Fig. 6 Changes of P515 signal in leaves of alfalfa seedlings with apical buds (a) and without apical buds (b), and $\mathrm{H}^{+}$-ATPase activity in shoots (c) of alfalfa seedlings with apical buds. Contents of $\operatorname{NADP}^{+}(\mathbf{d}), \mathrm{NADPH}(\mathbf{e})$ and $\mathrm{O}_{2}^{-}$(f) were measured in leaves of alfalfa seedlings without apical buds. Five treatments in the seedlings with apical buds are as Fig.2. Six treatments in the seedlings without apical buds are as Fig.3. All the data were measured on day 3. Data are means \pm SE of three independent replicates. Bars with different letters indicate significant difference at $P<$ 0.05 (Leas significant difference test) 
Transcriptome of alfalfa leaves after removed apical buds The effect of removing apical buds on transcriptome of alfalfa leaves was investigated using RNA-seq.

We focused on the genes classified into functional category of energy production and conversion. The genes in this category were most related to electron transport and energy pathways, and the number of genes involved in energy production and conversion was 694 in total (11 of them were upregulated and 3 of them were downregulated compared with normal seedlings, $|\log 2(\mathrm{FC})|>$ $=1 \& p$-value $<0.05)$. The complete list of differentially expressed genes (DEGs), their annotation, $p$ values, and fold changes, was provided as supplementary material (Additional file 6: Table S1). Among the 694 genes, 57 and 125 only expressed in normal and apical buds removed seedlings, respectively, and 512 expressed in both normal and apical buds removed seedlings (Fig.7a). Fourteen DEGs (eleven were upregulated and three were downregulated) related to energy production and conversion were functionally annotated with eggNOG (Additional file 7: Table S2) and their possible pathways were shown in Fig.7b, c.

\section{Discussion}

As a catalytic or structural cofactor of a large number of enzymes, Zn plays an important role in metabolic progresses related to photosynthesis and photochemistry. Carbonic anhydrase (CA) is a Zn-containing enzyme that catalyzes the reversible conversion of $\mathrm{CO}_{2}$ to $\mathrm{HCO}_{3}$ [21]. Application of $\mathrm{Zn}$ enhances the $\mathrm{CA}$ activity, which facilitates the supply of $\mathrm{CO}_{2}$ from the stomatal cavity to the site of $\mathrm{CO}_{2}$ fixation, and leads to Pn increase in pistachio seedlings under salt stress [9]. In the present study, application of Zn significantly increased the CA activity, as well as RuBisCO activity, leading to an increase of $\mathrm{Pn}$ under $\mathrm{Al}$ stress condition.

There are two electron transfer pathways related to proton motive force $(\mathrm{pmf})$ formation: linear electron flow and cyclic electron flow (CEF). The CEF can reduce electron accumulation in the acceptor side of PSI by oxidizing the acceptor-side components of PSI, and then regulate $p m f$ and proton gradient $(\Delta \mathrm{pH})$ of thylakoid. In the process, electrons recycle from PSI to plastoquinone (PQ) pool and Cytochrome $b_{6} f$ rather than to $\mathrm{O}_{2}$ to form ROS [22, 23]. In the present study, $\mathrm{Zn}$ addition increased $\mathrm{CEF}$ values of $\mathrm{Al}$-stressed alfalfa, which increased pmf and proton transfer from lumen to stroma $\left(\mathrm{g}_{\mathrm{H}}{ }^{+}\right)$, as well as decreased ROS generation (Fig.6f). The generation of pmf links to ATP synthesis and balances ATP/NADPH ratio [22, 24]. The increased $p m f$ and $\mathrm{g}_{\mathrm{H}}{ }^{+}$in $\mathrm{Al}$-stressed seedlings activated chloroplastic ATP synthase located in thylakoid membrane (Fig.6a), consequently increased ATP synthesis accompanying with $\mathrm{H}^{+}$transfer from lumen to stroma, which leads to a reduction of $\Delta \mathrm{pH}_{p m f}$ between lumen and stroma.

The $\Delta \mathrm{pH}_{p m f}$ formation controls modulation of PSII antenna light harvesting "switch", and negatively regulates the electron transfer from PSII to PSI [25]. Thus, the down-regulated CEF-dependent generation of $\Delta \mathrm{pH}_{p m f}$ by $\mathrm{Zn}$ addition prevented the $\mathrm{Al}$-induced reduction of oxidized state of quinone QA and reaction centers of photosystems, and increased abilities of PSI and PSII to endure high light intensity $\left(\mathrm{I}_{k}\right)$ (Additional file 5: Figre S5a, b). Meanwhile, the down-regulated $\Delta \mathrm{pH}_{p m f}$ by $\mathrm{Zn}$ addition increased the amount of active population of P700 (Fig.4c, f), which led to a high capacity of electron carriers in PSI and a high electron transfer from oxidized P700 to alternative electron acceptors of PSI, consequently, enhanced ETRII and ETRI.

In the photosynthetic process, $\mathrm{H}^{+}$-ATPase extrudes proton to create an electrochemical gradient (proton gradient, $\Delta \mathrm{pH}$ ) between the lumen and stroma by consuming ATP, which regulates electron transfer in photosystems and finally affects $\mathrm{CO}_{2}$ assimilation [16, 26, 27]. Auxin functions as a systemic signaling compound affecting $\mathrm{H}^{+}$transfer in cells and $\mathrm{H}^{+}$secretion from roots by activating plasma membrane $(\mathrm{PM}) \mathrm{H}^{+}$ATPase $[28,29]$. Thus, IAA and $\mathrm{H}^{+}$-ATPase play an important role in regulating membrane potential and proton gradient $(\Delta \mathrm{pH}) . \mathrm{Zn}$ is essential for auxin biosynthesis $[30,31]$. Our previous study showed that excess Al significantly decreased the IAA concentrations in leaves and root tips of alfalfa. However, this negative effect was alleviated by $\mathrm{Zn}$ addition [16]. In addition, exogenous application of IAA significantly increased PM $\mathrm{H}^{+}$-ATPase activity and $\mathrm{H}^{+}$secretion from root tips of alfalfa under $\mathrm{Al}$ stress [32]. These results indicate that $\mathrm{Zn}$ alleviates the Al-induced damage on photosynthetic machinery may be related to the increase of IAA synthesis and its effect on photosystems. An interaction between $\mathrm{Zn}$ and IAA might participate in alleviating $\mathrm{Al}$ induced inhibition on photosynthetic machinery. Thus, we further studied the interactive effect of $\mathrm{Zn}$ and IAA on regulating photosystems of $\mathrm{Al}$-stressed alfalfa seedlings with or without apical buds by exogenous application of IAA.

Exogenous application of IAA, in combine with $\mathrm{Zn}$, increased pmf compared with $\mathrm{Al}$ stress alone, as well as compared with $\mathrm{Zn}$ or IAA addition alone under $\mathrm{Al}$ stress. The increased $p m f$, combined with the highest $\mathrm{H}^{+}$-ATPase activity, promoted ATP synthase activity on thylakoid membrane (Fig.6a) and increased ATP synthesis and $\mathrm{H}^{+}$transfer from lumen to stroma [32]. These would ameliorate $\mathrm{H}^{+}$environment in cells of $\mathrm{Al}$-stressed seedlings, and led to highest quantum yields of Y(II) and Y(I) among the five treatments, accounted for 74.8 and $55.5 \%$ of the total excitation energy in PSI and PSII, 


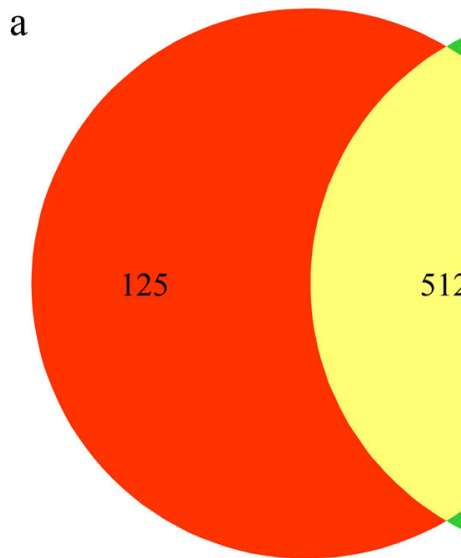

Apical buds removed

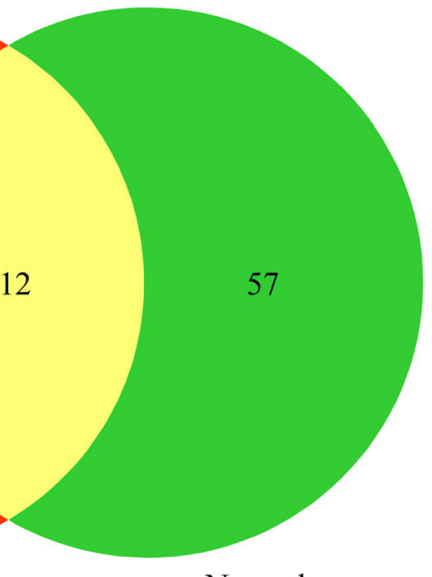

Normal

b

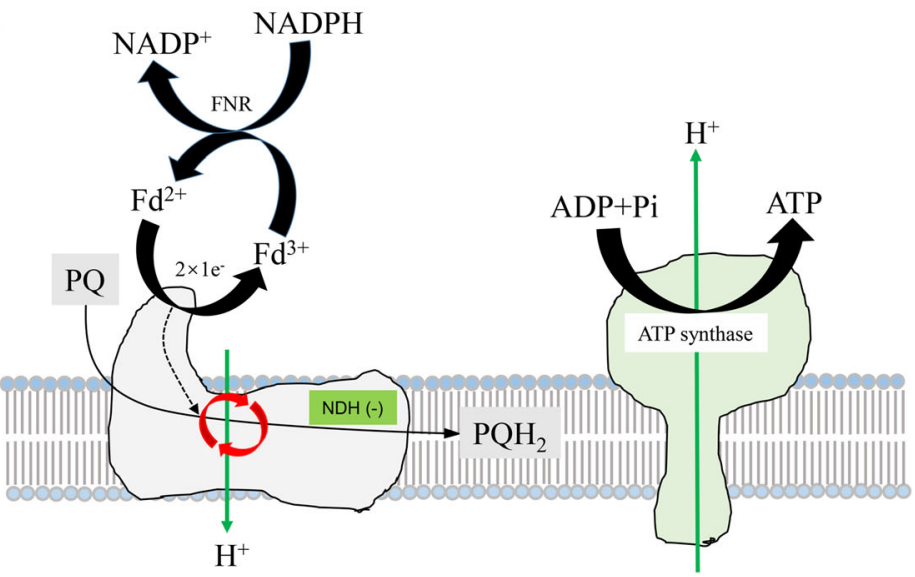

C

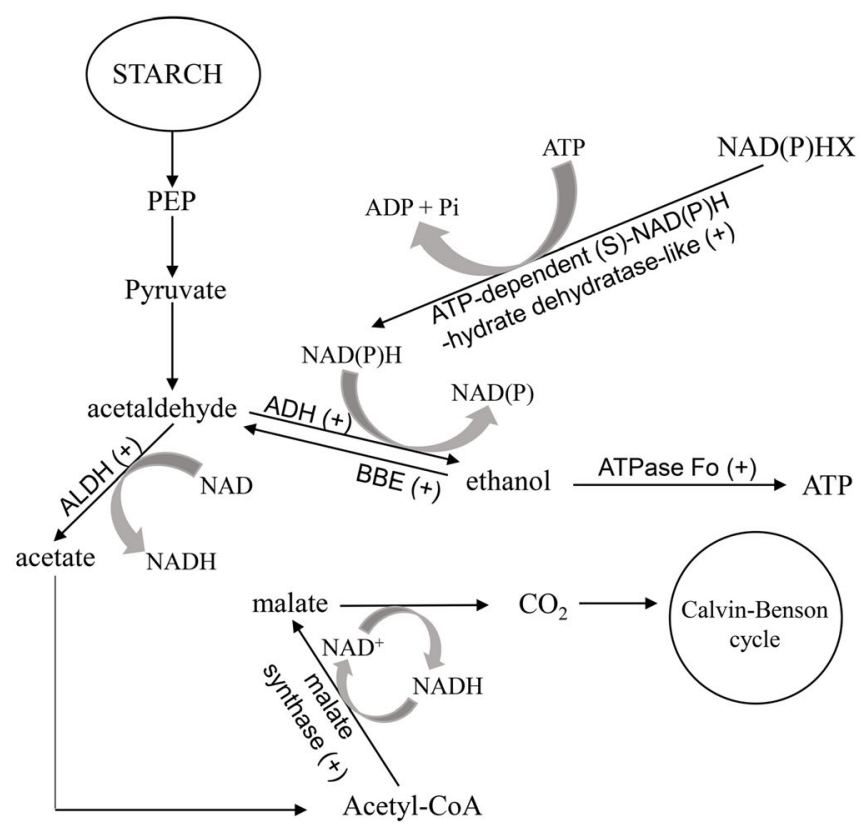

Fig. 7 (See legend on next page.) 
(See figure on previous page.)

Fig. 7 The genes related to energy production and conversion in RNA-seq assays from leaves of alfalfa seedlings with or without apical buds. a the number of genes involved in energy production and conversion was 694 in total, 57 and 125 only expressed in normal and apical buds removed seedlings, respectively, and 512 expressed in both normal and apical buds removed seedlings. The possible pathways in which DEGs involved were shown in (b) \& (c), - represented downregulated genes, + represented upregulated genes. The gene_ids were listed in Additional file 7: Table S2

respectively. The increased quantum yields effectively decreased the amount of non-photochemical energy dissipation and provided enough excited state energy to activate reaction centers and energy transfer to PSII and PSI, rather than energy transfer from chlorophyll to oxygen, resulting in less ROS production (Fig.6f). In addition, the highest values of active population of P700 (Fig.4c) and CEF (Fig.5a) were observed in $\mathrm{Zn}+$ IAA treatment under $\mathrm{Al}$ stress, indicating a low level of electron accumulation in PSI, which would protect P700 and increase ETRII and ETRI. These results implies that the interaction of $\mathrm{Zn}$ and IAA greatly alleviated the $\mathrm{Al}$ toxicity on photosynthetic machinery.

Our previous study showed that most of IAA was synthesized in apical buds of alfalfa. Removing apical buds would cause IAA concentration decrease to a very

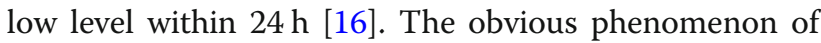
IAA natural decrease after removing apical buds was used in present study to further test the interactive effect of $\mathrm{Zn}$ and IAA on photosystems of Al-stressed alfalfa seedlings. In the study, the apical buds were removed and the seedlings were sprayed with water or IAA. Under none spraying IAA, the values of $\mathrm{Y}(\mathrm{II})$, $p m f$, $\Delta \mathrm{pH}_{p m f}$ and $\mathrm{g}_{\mathrm{H}}{ }^{+}$were not significantly different after $\mathrm{Zn}$ addition compared with $\mathrm{Al}$ treatment alone, however, $\mathrm{Zn}$ addition significantly increased $p m f$, and decreased $\Delta \mathrm{pH}_{p m f}$ after spraying IAA. Meanwhile, Y(I), Y(II), ETRI and ETRII also significantly increased under the treatment, and they were highest among all six treatments. The removing apical bud study clearly demonstrates that the interaction of $\mathrm{Zn}$ and IAA directly affects $p m f$ and $\Delta \mathrm{pH}_{p m f}$ formation under $\mathrm{Al}$ stress, thus, affects proton and electron transfer in cells.

$\mathrm{Zn}$ can interfere with ROS generation produced by the membrane-bound NADPH oxidase [33], which depends on pmf and $\mathrm{H}^{+}$-ATPase. In the removing apical bud study, the content of $\mathrm{O}_{2}{ }^{-}$significantly decreased after $\mathrm{Zn}$ addition compared with $\mathrm{Al}$ treatments, and the lowest content of $\mathrm{O}_{2}^{-}$occurred in $\mathrm{Zn}$ addition combined with spraying IAA (Fig.6f), indicating that the increased pmf regulates more electron transfer to generate NADP $\mathrm{H}$ rather than to generate $\mathrm{ROS}$ under $\mathrm{Al}$ stress. Concomitantly, this interaction induced increases of RuBisCO activity (Fig. 2b) and $\mathrm{CO}_{2}$ assimilation (Pn) would consume much of linear electron flow products (ATP and NADPH), which led to a reduction of NADP
$\mathrm{H}$ accumulation and an increase of $\mathrm{NADP}^{+}$accumulation. These would further promote electron transfer to $\mathrm{NADPH}$ generation rather than to ROS generation in chloroplast under $\mathrm{Al}$ stress. Thus, the interaction of $\mathrm{Zn}$ and IAA alleviated Al-induced photoinhibition in photosystems may greatly attribute to decreasing ROS generation.

Cyclic electron flow (CEF) around PSI produces only ATP, with no accumulation of $\mathrm{NAD}(\mathrm{P}) \mathrm{H}$. In the process, two partially redundant pathways are involved. The major pathway is mediated by a complex containing PROTON GRADIENT REGULA-TION 5 (PGR5) and PGR5-Like1 (PGRL1). The minor pathway depends on the activity of the chloroplast NADH dehydrogenase-like (NDH) complex, a homolog to respiratory Complex I. This pathway is thought to prevent over-reduction of the chloroplast stroma in $\mathrm{C}_{3}$ plants, especially under abiotic stress conditions [34], where the NDH pumps approximately two protons from the chloroplast stroma to lumen per electron transferred from ferredoxin to plastoquinone, which effectively increases the efficiency of ATP production via CEF [35]. The coupling of proton and electron transfer reactions within NDH allows electron transfer from plastoquinol to NADPH to be driven by the thylakoid pmf [36]. In the present study, transcriptome analysis demonstrated that the $N A D H$ dehydrogenase gene was down-regulated in the leaves of removed apical bud seedlings, which might reduce electron transfer from ferredoxin to plastoquinone, and decrease ATP production. The decreased NADH expression was consistent with the decrease of P515 signal in leaves of removed apical bud seedlings. In plants, Zeaxanthin enhances NPQ induction in bright light. By contrast, a low-light environment causes a decrease in the proton gradient that activates the enzyme zeaxanthin epoxidase (ZEP), this converts zeaxanthin back into violaxanthin and causes a decrease in NPQ induction. The down-regulated $Z E P$ expression in removed apical bud seedlings would keep a higher level of zeaxanthin and enhance NPQ induction, this would contribute to redundant energy dissipation in PSII and decrease electron transfer from PSII to PSI for photoprotection. These conclusions support the results of decreased ETR II and ETR I observed in removed apical bud seedlings. The above results of transcriptome analysis fully support our conclusion that IAA enhances Al tolerance of alfalfa via 
increasing $p m f$ and decreasing $\Delta \mathrm{pH}_{p m f}$ between lumen and stroma.

The effect of IAA on carbon fixation and energy production can also be clearly reflected from molecular regulation pathways of energy production and conversion. In plants, anaerobic activation of fermentative pathways constitutes an efficient solution to restore the pool of oxidized $\mathrm{NAD}^{+}$, while at the same time, avoiding pyruvate and succinate accumulation. Two fermentative pathways are expected to contribute mainly to glycolysis maintenance in plants: lactate and ethanol fermentation [37]. In the pathways, pyruvate is catalyzed by pyruvate decarboxylase (PDC) and a zinc-binding alcohol dehydrogenase (ADH), using $\mathrm{NAD}^{+}$or $\mathrm{NADP}^{+}$as a cofactor, and generates acetaldehyde and ethanol [38]. The ethanol either in allylic or benzylic form also can be oxidized to the corresponding aldehydes by berberine bridge enzyme (BBE) [39]. Aldehydes are highly reactive molecules, and are toxic at high concentrations. Aldehyde dehydrogenases (ALDHs), mitochondrial or cytosolic homotetrameric enzymes, oxidize acetaldehyde into acetate for biosynthesis of acetyl-CoA and malate, using $\mathrm{NAD}^{+}$or $\mathrm{NADP}^{+}$as a co-factor. As such ALDHs play an important role in detoxifying acetaldehyde in plants [38]. In the present study, PEPC, $A D H$, malate synthase (MS), two $A L D H$ genes $(A L D H 2-B 7, C 5)$ and three $B B E$ genes $(B B E 8,17$ and 18) were up-regulated in the leaves of removed apical bud seedlings, these might increase productions of ethanol, acetate and malate, while at the same time, the up-regulated $B B E s$ genes would avoid more ethanol accumulation to damage cells. Ethanol synthesis, accompanied with an up-regulated ATP synthase FO gene in the leaves of removed apical bud seedlings, allowed glycolysis to continue producing a small quantity of ATP [40]. Furthermore, up-regulated ATP-dependent (S)-NAD(P)H-hydrate dehydratase-like gene, a metabolite repair or metabolite-proofreading enzyme, in the leaves of removed apical bud seedlings might convert abnormal metabolite $\mathrm{NAD}(\mathrm{P}) \mathrm{H}$ hydrate $(\mathrm{NAD}(\mathrm{P}) \mathrm{HX})$ to $\mathrm{NAD}(\mathrm{P}) \mathrm{H}$ to restore the pool of $\mathrm{NADH}$ [41]. Thus, as a feedback response of IAA shortage in the seedlings of removed apical buds, ethanol synthesis and oxidation, as well as up-regulation of ATPdependent (S)-NAD(P)H-hydrate dehydratase gene helped to remediate mismatches of ATP and NAD $(\mathrm{P}) \mathrm{H}$ in the photosynthetic budget under down-regulated $N A D H$ dehydrogenase in the leaves of removed apical bud seedlings.

\section{Conclusion}

$\mathrm{Al}$ stress significantly damaged photosynthetic apparatus of alfalfa, however, application of $\mathrm{Zn}$ and IAA significantly alleviated the $\mathrm{Al}$-induced negative effects on photosystems. The interaction of $\mathrm{Zn}$ and IAA significantly increased quantum yields and electron transfer rates of PSI and PSII under Al stress. These positive effects were greatly attributed to the increases of $p m f, \mathrm{H}^{+}$-ATPase activity and ATP synthase activity, and the decrease of $\Delta \mathrm{pH}_{\text {pmf }}$ between lumen and stroma. As a result, more electrons transferred to NADPH generation rather than to ROS generation, which greatly protected photosystems against excess $\mathrm{Al}$ damage.

\section{Methods}

\section{Plant materials and growth conditions}

Alfalfa seeds (WL-525HQ), which obtained from the Chinese National Seed Group Corporation, Ltd., germinated on a filter paper moistened with $1 / 2$-strength Hoagland's nutrient solution at $25^{\circ} \mathrm{C}$. The uniform seedlings were transplanted to a foam board (12 holes/board; 6 seedlings/hole) floating on aerated $1 / 2$-strength Hoagland's nutrient solution ( $\mathrm{pH}$ 5.8) in plastic containers for $4 \mathrm{~d}$. The seedlings were placed in greenhouse, and conditions set to $25 / 20^{\circ} \mathrm{C}$ (day/night), 14-h photoperiod and a photon flux density of $400 \mu \mathrm{mol} \mathrm{m}^{-2} \mathrm{~s}^{-1}$. Solutions were replaced every $2 \mathrm{~d}$.

\section{Treatments and experimental design}

Our previous study showed that $\mathrm{Al}$ stress reduced the contents of $\mathrm{Zn}, \mathrm{Ca}, \mathrm{Mg}, \mathrm{Mn}$ and $\mathrm{K}$ in roots of alfalfa seedlings grown in $1 / 2$-strength Hoagland's nutrient solution [42], but increased Fe content. The Al-induced imbalance of cation levels in plants will make us difficulty to distinguish the effect of $\mathrm{Zn}$ on alleviation of Al-induced photosystem damage. To avoid the imbalance of cation levels to disturb our identification on Zn's effect on photosystem of alfalfa seedlings in Hoagland's nutrient solution, a simple solution $\left(1.5 \mathrm{mM} \mathrm{Ca}\left(\mathrm{NO}_{3}\right)_{2}\right)$ was used in this study according to Sun et al. [43].

Experimental one: The interaction of $\mathrm{Zn}$ and IAA on photosystems of alfalfa seedlings with apical buds under $\mathrm{Al}$ stress. The dosage of $50 \mu \mathrm{M} \mathrm{Zn}$ was used in the experiments according to our preliminary experiments (Additional file 1: Figure S1). The alfalfa seedlings were placed in $1.5 \mathrm{mM} \mathrm{Ca}\left(\mathrm{NO}_{3}\right)_{2}$ solution ( $\left.\mathrm{pH} 4.5\right)$ supplemented with $0 \mu \mathrm{M} \mathrm{AlCl} 3$ (pH 4.5), or $100 \mu \mathrm{M} \mathrm{AlCl}_{3}$ with or without spraying $6 \mathrm{mg} \mathrm{L}^{-1}$ IAA ( $\mathrm{pH} 4.5+\mathrm{Al}, \mathrm{pH} 4.5+$ $\mathrm{Al}+\mathrm{IAA}$ ), or $100 \mu \mathrm{M} \mathrm{AlCl}{ }_{3}$ and $50 \mu \mathrm{M} \mathrm{ZnCl}$ with or without spraying $6 \mathrm{mg} \mathrm{L}^{-1}$ IAA $(\mathrm{pH} 4.5+\mathrm{Al}+\mathrm{Zn}, \mathrm{pH}$ $4.5+\mathrm{Al}+\mathrm{Zn}+\mathrm{IAA})$.

In addition, the seedlings were treated with $1.5 \mathrm{mM}$ $\mathrm{Ca}\left(\mathrm{NO}_{3}\right)_{2}$ solution ( $\mathrm{pH} 4.5$ ) supplemented with $100 \mu \mathrm{M}$ $\mathrm{AlCl}_{3}(\mathrm{Al})$ either alone or in combined with $25 \mu \mathrm{M}$ or $50 \mu \mathrm{M} \mathrm{ZnCl}{ }_{2}$ to observe the variation of IAA contents in seedlings. The $1.5 \mathrm{mM} \mathrm{Ca}\left(\mathrm{NO}_{3}\right)_{2}$ solution with $\mathrm{pH} 4.5$ was used as control treatment.

Experimental two: The interaction of $\mathrm{Zn}$ and IAA on photosystems of alfalfa seedlings without apical buds 
under $\mathrm{Al}$ stress. Most of IAA were synthetized in apical bud of alfalfa, and removing apical buds greatly decreased the IAA content in alfalfa [16]. To further explore the interaction of $\mathrm{Zn}$ and IAA on protecting photosystems under $\mathrm{Al}$ stress, a removing apical bud experiment was conducted. After $3 \mathrm{~d}$ of apical buds removed, the seedlings were placed in $1.5 \mathrm{mM} \mathrm{Ca}\left(\mathrm{NO}_{3}\right)_{2}$ solution ( $\mathrm{pH}$ 4.5) supplemented with $0 \mu \mathrm{M} \mathrm{AlCl}_{3}$ with or without spraying IAA (pH 4.5-IAA, $\mathrm{pH} 4.5+\mathrm{IAA})$, or $100 \mu \mathrm{M} \mathrm{AlCl}{ }_{3}$ with or without spraying IAA (pH $4.5+$ Al-IAA, pH $4.5+\mathrm{Al}+\mathrm{IAA})$ or $100 \mu \mathrm{M} \mathrm{AlCl} 3$ and $50 \mu \mathrm{M}$ $\mathrm{ZnCl}_{2}$ with or without spraying IAA $(\mathrm{pH} 4.5+\mathrm{Al}+\mathrm{Zn}$ IAA, $\mathrm{pH} 4.5+\mathrm{Al}+\mathrm{Zn}+\mathrm{IAA})$.

Each treatment in the above experiments was replicated three times and all measurements or plant sample collection were conducted at the 3rd day.

\section{Measurement of gas exchange, chlorophyll fluorescence and P700 parameters}

Five leaves per treatment were used for measurements of net photosynthetic rate $\left(\mathrm{P}_{\mathrm{n}}\right)$ with GFS-3000 (Walz, Germany) under the light intensity at $800 \mu \mathrm{mol} \mathrm{m}^{-2} \mathrm{~s}^{-1}$ and air flow rate at $750 \mu \mathrm{mol} \mathrm{s}^{-1}$. The measurements were conducted three times independently.

Chlorophyll fluorescence and P700 parameters were measured simultaneously by Dual-PAM-100 system (Walz, Germany). Prior to measurements, all plants were in the dark for more than $2 \mathrm{~h}$, and fluorescence induced curve (Slow Kinetics) was determined in 'Fluo+P700' mode. Then, the kinetics of chlorophyll fluorescence induction and P700 oxidation were recorded simultaneously from the instrument. The light-adapted photosynthetic parameters were recorded after exposure to different light intensity $(1445,1105,819,592,418,206$, 69, 36, $13 \mu \mathrm{mol}$ photons $\left.\mathrm{m}^{-2} \mathrm{~s}^{-1}\right)$ for $240 \mathrm{~s}$. The chlorophyll fluorescence parameters $F v / F m, Y(I I), Y(N P Q)$ and $Y(N O)$ were calculated as described in Huang et al. [44]. P700 parameters were measured and calculated as described in Yuan et al. [45] and Huang et al. [46].

Photosynthetic electron flow through PSI or PSII were calculated as: ETRII $=\mathrm{Y}(\mathrm{II}) \times \mathrm{PPFD} \times 0.84 \times 0.5$, $\mathrm{ETRI}=\mathrm{Y}(\mathrm{I}) \times \mathrm{PPFD} \times 0.84 \times 0.5$ [47]. The value of cyclic electron flow (CEF) was estimated as ETRI-ETRII [44]. Chlorophyll fluorescence images of treated leaves were measured at room temperature with an imaging PAM (Imaging WinGigE, Walz, Germany) after darkadapting plants for $1 \mathrm{~h}$, according to procedures described in Xia et al. [48].

$\mathrm{I}_{k}$ is minimum saturating irradiance and reflects tolerance ability of photosystems to high light intensity. The value of $I_{k}$ was estimated using the empirical equation of rapid light curve (RLC) proposed by Eilers and Peeters [49].
Total proton motive force $(p m f), \mathrm{g}_{\mathrm{H}}{ }^{+}$and proton gradient $(\Delta \mathrm{pH})$ across the thylakoid membranes were estimated from the total amplitude of the rapid decay of the ECS signal as described in Li et al. [50] and Huang et al. [44]. Alfalfa seedlings were first dark-adapted for 1 h before ECS signal was detected. The P515/P535 was measured according to Zhang et al. [51] and Li et al. [50], and the ATPase activity was evaluated from P515 changes induced by saturating single turnover flashes.

With regard to the above-mentioned experiments, at least 6 different leaves from different seedlings were used for each treatment.

\section{Assay of RuBisCO activity, carbonic anhydrase activity, $\mathrm{H}^{+}$-ATPase activity, and contents of IAA, NADP ${ }^{+}, \mathrm{NADPH}$, superoxide anion $\left(\mathrm{O}_{2}{ }^{-}\right), \mathrm{Al}$ and $\mathrm{Zn}$}

The activities of RuBisCO, carbonic anhydrase and plasma membrane $\mathrm{H}^{+}$-ATPase were measured using commercial enzyme-linked immunoassay (ELISA) kits according to the manufacturer's instruction (JL22727 \& JL22872 \& JL49554, Jianglai biotech, China). Briefly, about $1 \mathrm{~g}$ fresh shoots from different treatments were homogenized in 9 $\mathrm{mL}$ cold phosphate buffer (PBS, $0.01 \mathrm{M}, \mathrm{pH} 7.40$ ) on ice. The homogenates were then centrifuged at $5000 \times$ g for 10 min at $4{ }^{\circ} \mathrm{C}$. The extract (supernatants) from plants captures the antibody and encapsulates the antibody onto the micropore plate to make the solid phase antibody. Then, the samples (RuBisCO, carbonic anhydrase or $\mathrm{H}^{+}$ATPase) were added to the encapsulated micropore and combined with the labeled antibody to form the antibody antigen-enzyme-labeled antibody complex. After a thorough washing, the substrate TMB was added and colored. The color is positively correlated with the activities of $\mathrm{RuBisCO}$, carbonic anhydrase or $\mathrm{H}^{+}$-ATPase. Finally, the absorbance was determined immediately at $450 \mathrm{~nm}$, and the activities of these enzymes were calculated with a standard curve.

The contents of NADP ${ }^{+}$and NADPH were determined according to the manufacturer's instruction (Cominbio, Suzhou, China). Briefly, about $0.1 \mathrm{~g}$ fresh shoots from different treatments was ground into homogenate with $1 \mathrm{~mL}$ acidic extracting solution (for $\mathrm{NADP}^{+}$) or $1 \mathrm{~mL}$ alkaline extracting solution (for NADPH) in a mortar on ice. The homogenate was then transferred to a $1.5 \mathrm{~mL}$ Eppendorf tube and immersed in a water-bath at $95^{\circ} \mathrm{C}$ for $5 \mathrm{~min}$, quickly cooled in ice bath and centrifuged at $10000 \times \mathrm{g}$ for $10 \mathrm{~min}$ at $4{ }^{\circ} \mathrm{C}$. The $500 \mu \mathrm{L}$ supernatant was collected in a new tube and another $500 \mu \mathrm{L}$ alkaline extracting solution (for $\mathrm{NADP}^{+}$) or $500 \mu \mathrm{L}$ acidic extracting solution (for $\mathrm{NADPH}$ ) were added to neutralize, then mixed and centrifuged at $10000 \times \mathrm{g}$ for $10 \mathrm{~min}$ at $4{ }^{\circ} \mathrm{C}$. The supernatants were collected for analysis.

$\mathrm{Al}$ and $\mathrm{Zn}$ contents were determined according to Wang et al. [32] with minor modification. Briefly, fresh 
samples from treated plants were oven-dried for $72 \mathrm{~h}$ at $80^{\circ} \mathrm{C}$, and then grounded to fine powder. A $0.5 \mathrm{~g}$ powder was digested in a 1:1 (v/v) nitric acid/hydrogen peroxide solution $\left(\mathrm{HNO}_{3} / \mathrm{H}_{2} \mathrm{O}_{2}\right)$. Al and $\mathrm{Zn}$ contents were then determined using an inductively coupled plasma emission spectrometer (ICP-AES; Iris Advantage 1000, Jarrell Ash Corp. Franklin, Massachusetts, USA).

IAA content was determined following Wang et al. [16], and $\mathrm{O}_{2}{ }^{-}$content was measured according to the manufacturer's instruction (Cominbio, Suzhou, China), fresh samples were used and the extraction of $\mathrm{O}_{2}{ }^{-}$were conducted at low temperature $\left(4^{\circ} \mathrm{C}\right.$ or in an ice bath). Three biological repeats were performed for each of above experiment.

\section{RNA-seq analysis}

After part of alfalfa seedlings (12 d from germination) were removed apical buds for $48 \mathrm{~h}$, the total RNA samples were isolated from the alfalfa seedlings with or without apical buds by using TransZol Up Plus RNA Kit (TransGen Biotech. China) following the manufacturer's instruction. The quality control was performed using an Agilent 4200 Bioanalyzer (Agilent Technologies Inc.). To analyze the transcriptome, RNASeq libraries were prepared from cDNA by Instrumental Analysis Center (Shanghai Jiao Tong University, Shanghai, China) and sequenced on an Illumina NovaSeq 6000 (Illumina Inc., San Diego, CA, USA). Raw sequencing reads were screened with the FASTP software (Version 0.20.0) to cut out low quality or default reads. All gained clean reads were assembled to Transcripts or Unigenes using TRINITY software (Version 2.8.5). Gene expression (FPKM) and differential expression levels were analyzed using RSEM and edgeR software. We gained gene function annotation from the assembled Unigenes using BLAST and diamond software (Version 0.8.22) with the NCBI-NR (nonredundant) database, Swiss-Prot, eggNOG, GO and KEGG.

\section{Statistical analysis}

All of the treatments were repeated three times, and the data were assessed from the results of three independent experiments. Data was analyzed by variance (ANOVA) using SAS 9.0 (SAS Institute Inc., Cary, NC, USA) and the means were compared by least significant difference (LSD) at $P=0.05$ level. Different letters on the histograms indicate statistical differences at the level of $P<0.05$.

\section{Supplementary information}

Supplementary information accompanies this paper at https://doi.org/10 1186/s12870-020-02643-6.

Additional file 1 Figure S1. Root length of alfalfa seedlings grown in $1.5 \mathrm{mM} \mathrm{Ca}\left(\mathrm{NO}_{3}\right)_{2}$ medium $(\mathrm{pH} 4.5)$ containing $0 \mu \mathrm{M} \mathrm{AlCl}$ ( $(\mathrm{pH} 4.5), 100 \mu \mathrm{M}$ $\mathrm{AlCl}_{3}(\mathrm{pH} 4.5+\mathrm{Al}), 100 \mu \mathrm{M} \mathrm{AlCl} 3$ and $25 \mu \mathrm{M} \mathrm{ZnCl} 2(\mathrm{pH} 4.5+\mathrm{Al}+25 \mu \mathrm{M}$
$\mathrm{Zn})$, or $100 \mu \mathrm{M} \mathrm{AlCl}_{3}$ and $50 \mu \mathrm{M} \mathrm{ZnCl}(\mathrm{pH} 4.5+\mathrm{Al}+50 \mu \mathrm{M} \mathrm{Zn})$ on days 1 , 3 and 6 . Data are means \pm SE of three replicates from three independent experiments. Bars with different letters in the same day indicate significant difference at $P<0.05$ (Leas significant difference test).

Additional file 2 Figure S2. Al contents in roots (a) and shoots (b), Zn contents in roots (c) and shoots (d) and $\mathrm{Al} / \mathrm{Zn}$ ratio in roots (e) and shoots $(f)$ of alfalfa seedlings with apical buds grown in $1.5 \mathrm{mM} \mathrm{Ca}\left(\mathrm{NO}_{3}\right)_{2}$ medium (pH 4.5) containing $0 \mu \mathrm{M} \mathrm{AlCl} 3(\mathrm{pH} 4.5), 100 \mu \mathrm{M} \mathrm{AlCl}(\mathrm{pH} 4.5+$ Al), $100 \mu \mathrm{M} \mathrm{AlCl}$ and $50 \mu \mathrm{M} \mathrm{ZnCl}(\mathrm{pH} 4.5+\mathrm{Al}+\mathrm{Zn}), 100 \mu \mathrm{M} \mathrm{AlCl}$ and 6 $\mathrm{mg} \mathrm{L}^{-1}$ IAA (foliar spray) (pH 4.5 + Al + IAA) or $100 \mu \mathrm{M} \mathrm{AlCl}$ and $50 \mu \mathrm{M}$ $\mathrm{ZnCl}_{2}$ and $6 \mathrm{mg} \mathrm{L}^{-1}$ IAA (foliar spray) ( $\left.\mathrm{pH} 4.5+\mathrm{Al}+\mathrm{Zn}+\mathrm{IAA}\right)$ on 3 days. Data are means \pm SE of three replicates from three independent experiments. Bars with different letters indicate significant difference at $P<0.05$ (Leas significant difference test).

Additional file $\mathbf{3}$ Figure $\mathbf{S} \mathbf{3}$. Light intensity dependence of photosynthetic quantum yields of $Y(N D)$ and $Y(N A)$ in $P S I$ and $Y(N P Q)$ and $Y(N O)$ in PSII in leaves of alfalfa seedlings with or without apical buds. Five treatments in the seedlings with apical buds are as Fig.3, and seedlings without apical buds are grown in $1.5 \mathrm{mM} \mathrm{Ca}\left(\mathrm{NO}_{3}\right)_{2}$ medium $(\mathrm{pH} 4.5)$ and treated with or without spraying IAA ( $\mathrm{pH} 4.5-\mathrm{IAA}, \mathrm{pH} 4.5+$ IAA), $100 \mu \mathrm{M} \mathrm{AlCl}_{3}$ with or without spraying IAA (pH 4.5 + Al-IAA, pH $4.5+$ $\mathrm{Al}+\mathrm{IAA}$ ) and $100 \mu \mathrm{M} \mathrm{AlCl}_{3}$ and $50 \mu \mathrm{M} \mathrm{ZnCl}_{2}$ with or without spraying IAA $(\mathrm{pH} 4.5+\mathrm{Al}+\mathrm{Zn}-\mathrm{IAA}, \mathrm{pH} 4.5+\mathrm{Al}+\mathrm{Zn}+\mathrm{IAA})$. The (a) $\mathrm{Y}(\mathrm{ND}),(\mathrm{b}) \mathrm{Y}(\mathrm{NA})$, (c) $Y(N P Q)$ and $(d) Y(N O)$ were estimated from seedlings with apical buds, and (e) $Y(N D)$, (f) $Y(N A),(g) Y(N P Q)$ and (h) $Y(N O)$ were estimated from seedlings without apical buds on 3 days. At least 6 different leaves from different seedlings were used for each treatment and data are means \pm SE of three replicates. Bars with different letters indicate significant difference at $P<0.05$ (Leas significant difference test).

Additional file $\mathbf{4}$ Figure S4. Images of chlorophyll fluorescence in leaves of alfalfa seedlings with apical buds grown in $1.5 \mathrm{mM} \mathrm{Ca}\left(\mathrm{NO}_{3}\right)_{2}$ medium (pH 4.5) containing $0 \mu \mathrm{M} \mathrm{AlCl}_{3}(\mathrm{pH} 4.5), 100 \mu \mathrm{M} \mathrm{AlCl}(\mathrm{pH} 4.5+$ $\mathrm{Al}), 100 \mu \mathrm{M} \mathrm{AlCl}$ and $50 \mu \mathrm{M} \mathrm{ZnCl}(\mathrm{pH} 4.5+\mathrm{Al}+\mathrm{Zn}), 100 \mu \mathrm{M} \mathrm{AlCl}$ and 6 $\mathrm{mg} \mathrm{L}^{-1}$ IAA (foliar spray) (pH 4.5+ Al + IAA) or $100 \mu \mathrm{M} \mathrm{AlCl}$ and $50 \mu \mathrm{M}$ $\mathrm{ZnCl}_{2}$ and $6 \mathrm{mgL}^{-1}$ IAA (foliar spray) ( $\mathrm{pH} 4.5+\mathrm{Al}+\mathrm{Zn}+\mathrm{IAA}$ ) on 3 days. At least 6 different leaves from different seedlings were used for each treatment with the similar results.

Additional file $\mathbf{5}$ Figure $\mathbf{S 5}$. Effects of $\mathrm{Zn}$ and IAA on minimum saturating irradiance $\left(I_{k}\right)$ in PSI (a) and PSII (b) of seedlings with apical buds under Al stress. At least 6 different leaves from different seedlings were used for each treatment and data are means \pm SE of three replicates. Values followed by different letters are significantly different at $p \leq 0.05$ (Leas significant difference test).

Additional file 6 Table S1. Genes with differential expression in alfalfa leaves between normal seedlings and apical buds removed seedlings.

Additional file $\mathbf{7}$ Table S2. Differential expression gens involved in energy production and conversion are identified with a FDR $<0.05$ and $\log 2|\mathrm{FC}|>=1$ from leaves of normal seedlings and buds removed seedlings.

\section{Abbreviations}

P700/P700': PSI reaction center chlorophyll dimer/oxidized form of primary electron donor of PSI; PSI and PSII: Photosystem I and II, respectively; Y(I) and $Y(I I)$ : The quantum yield of PSI and PSII, respectively; Y(ND) and Y(NA): The quantum yield of non-photochemical energy dissipation in PSI owing to a shortage of electron donors[Y(ND)] or electron acceptors [Y(NA)]; $\mathrm{Y}(\mathrm{NPQ})$ : The quantum yield of regulated energy dissipation in PSII; $Y(N O)$ : The quantum yield of non-regulated energy dissipation in PSII; ETRI and ETRII: Photosynthetic electron flow through PSI and PSII, respectively; pmf: Proton motive force; $\Delta \mathrm{pH}$ : Trans-thylakoid $\mathrm{pH}$ difference or proton gradient; Pn: Net photosynthetic rate; $\mathrm{g}_{\mathrm{H}}^{+}$: Proton efflux rate; $\mathrm{l}_{k}$ : Minimum saturating irradiance; $\mathrm{O}_{2}^{-}$: Superoxide anion; $\mathrm{NDH}$ : NADH dehydrogenase-like (complex); ALDH: Aldehyde dehydrogenase; ADH: Alcohol dehydrogenase; PEP: Phosphoenolpyruvate; BBE: Berberine bridge enzyme

\section{Acknowledgements}

We thank Prof. Yanbang Li for language editing. We also thank the technicians Baogang Zheng and Shuai Shang (Zealquest Scientific 
Technology Co., Ltd., Shanghai) for their guidance teaching us to use DualPAM-100 and GFS-3000.

\section{Authors' contributions}

LTS and YA designed the research, LTS performed most of the experiments writing the original draft. PJX and WWW performed some experiments and analyzed part of the data. JJL and PZ analyzed part of the data. YA provided the guidance during all experiments and revised the manuscript. All authors have read and approved the manuscript.

\section{Funding}

This work was financially supported by National Key R\&D Program of China (No2017FY100600) and National Natural Science Foundation Projects of China (Nos. 31872408 and Nos. 31872419).

\section{Availability of data and materials}

The datasets supporting the conclusions of this research and materials used in this research are available by contacting with the corresponding author (anyuan@sjtu.edu.cn). The transcriptome data are shown in additional files Table S1 and Table S2.

\section{Ethics approval and consent to participate}

Not applicable.

\section{Consent for publication}

Not applicable.

\section{Competing interests}

The authors declare that they have no competing interests.

Received: 1 January 2020 Accepted: 9 September 2020

Published online: 18 September 2020

\section{References}

1. Kochian LV, Hoekenga OA, Pineros MA. How do crop plants tolerate acid soils? Mechanisms of aluminum tolerance and phosphorous efficiency. Annu Rev Plant Biol 2004;55:459-493. https://doi.org/10.1146/annure v. arplant.55.031903.141655.

2. Derks A, Schaven K, Bruce D. Diverse mechanisms for photoprotection in photosynthesis. Dynamic regulation of photosystem II excitation in response to rapid environmental change Biochim Biophys ActaBioenergetics 2015;1847:468-485. https://doi.org/https://doi.org/10.1016/j. bbabio.2015.02.008.

3. Hasni I, Msilini N, Hamdani S, Tajmir-Riahi HA, Carpentier R. Characterization of the structural changes and photochemical activity of photosystem I under $\mathrm{A}^{3+}$ effect. J Photoch Photobio B. 2015;149:292-299. https://doi. org/ https://doi.org/10.1016/j.jphotobiol.2015.06.012.

4. Roach T, Krieger-Liszkay A. Regulation of photosynthetic electron transport and photoinhibition. Curr Prot Pept Sci 2014;15:351-362. https://doi.https:// doi.org/10.2174/1389203715666140327105143.

5. Davis GA, Kanazawa A, Schöttler MA, Kohzuma K, Froehlich JE, Rutherford AW, Satoh-Cruz M, Minhas D, Tietz S, Dhingra A, Kramer DM Limitations to photosynthesis by proton motive force-induced photosystem II photodamage Elife 2016;5:e16921. https://doi.https://doi.org/10.7554/eLife. 16921.

6. Moustaka J, Ouzounidou G, Bayçu G, Moustakas M. Aluminum resistance in wheat involves maintenance of leaf $\mathrm{Ca}^{2+}$ and $\mathrm{Mg}^{2+}$ content, decreased lipid peroxidation and $\mathrm{Al}$ accumulation, and low photosystem II excitation pressure. Biometals 2016;29:611-623. https://doi.org/https://doi.org/10.1007/ s10e534-016-9938-0.

7. Mattiello EM, Ruiz HA, Neves JC, Ventrella MC, Araújo WL. Zinc deficiency affects physiological and anatomical characteristics in maize leaves. J Plant Physiol. 2015;183:138-143. https://doi. org/https://doi.org/10.1016/j.jplph. 2015.05.014.

8. Malasarn D, Kro Pat J, Hsieh I, Finazzi G, Casero D, Loo JA, Pellegrini M, Wollman FA, Merchant SS. Zinc deficiency impacts $\mathrm{CO}_{2}$ assimilation and disrupts copper homeostasis in Chlamydomonas reinhardtii. J Biol Chem 2013;288:10672-10683. https://doi.https://doi.org/10.1074/jbc.M113.455105.

9. Tavallali V, Rahemi M, Maftoun M, Panahi B, Karimi S, Ramezanian A, Vaezpour M. Zinc influence and salt stress on photosynthesis, water relations, and carbonic anhydrase activity in pistachio. Sci Hortic 2009;123: 272-279. https://doi.org/https://doi.org/10.1016/.scienta.2009.09.006.

10. Fernàndez-Martínez J, Zacchini M, Fernández-Marín B, García-Plazaola JI, Fleck I. Gas-exchange, photo-and antioxidant protection, and metal accumulation in 1-214 and Eridano Populus sp. clones subjected to elevated zinc concentrations. Environ Exp Bot 2014;107:144-153. https://doi.org/ https://doi.org/10.1016/j.envexpbot.2014.06.004.

11. Amiri A, Baninasab B, Ghobadi C, Khoshgoftarmanesh AH. Zinc soil application enhances photosynthetic capacity and antioxidant enzyme activities in almond seedlings affected by salinity stress. Photosynthetica. 2016;54:267-274. https://doi.org/https://doi.org/10.1007/s1 1099-016-0078-0.

12. Bayçu G, Gevrek-Kürüm N, Moustaka J, Csatári I, Rognes SE, Moustakas M. Cadmium-zinc accumulation and photosystem II responses of Noccaea caerulescens to cd and Zn exposure. Environ Sci Pollut Res 2017;24: 28402850. https://doi.org/https://doi.org/10.1007/s11356-016-8048-4.

13. Tiecher TL, Soriani HH, Tiecher T, Ceretta CA, Nicoloso FT, Tarouco CP, Clasen BE, Conti LD, Tassinari A, Melo G, Brunetto G. The interaction of high copper and zinc doses in acid soil changes the physiological state and development of the root system in young grapevines (Vitis vinifera). Ecotox Environ Safe 2018;148:985-994. https://doi.org/https:/doi.org/10.1016/j. ecoenv.2017.11.074

14. Andrejić G, Gajić G, Prica M, Dželetović Ž, Rakić T. Zinc accumulation, photosynthetic gas exchange, and chlorophyll a fluorescence in Zn-stressed Miscanthus X giganteus plants. Photosynthetica 2018;56:1249-1258. https:// doi.org/https://doi.org/10.1007/s11099-018-0827-3.

15. Singh S, Prasad SM. IAA alleviates cd toxicity on growth, photosynthesis and oxidative damages in eggplant seedlings. Plant Growth Regul 2015;77:8798. https://doi.org/https://doi.org/10.1007/s10725-015-0039-9.

16. Wang $S Y$, Ren $X Y$, Huang BR, Wang G, Zhou P, An Y. Aluminium-induced reduction of plant growth in alfalfa (Medicago sativa) is mediated by interrupting auxin transport and accumulation in roots. Sci Rep 2016;6: 30079:1-13. https://doi.org/https://doi.org/10.1038/srep30079.

17. Cui P, Liu H, Ruan S, Ali B, Gill RA, Ma H, Zheng Z, Zhou W. A zinc finger protein, interacted with cyclophilin, affects root development via IAA pathway in rice. J Integr Plant Biol. 2017;59: 496-505. https://doi.org /https://doi.org/10.1111/jipb.12531.

18. An Y, Zhou P, Xiao Q, Shi D. Effects of foliar application of organic acids on alleviation of aluminum toxicity in alfalfa. J Plant Nutr Soil Sci 2014;177:421430. https://doi.org/https://doi.org/10.1002/jpln.201200445.

19. Lin C, Hara A, Comparini D, Bouteau F, Kawano T. Zinc-dependent protection of tobacco and rice cells from aluminum-induced superoxidemediated cytotoxicity. Front Plant Sci 2015;6:1079. https://doi.org/https:// doi.org/10.3389/fpls.2015.01079.

20. Schreiber U, Klughammer C. New accessory for the DUAL-PAM-100: The P515/535 module and examples of its application. PAM Appl Notes. 2008;1: 1-10 Available online at: http://walz.com/downloads/pan/ PAN07001_e d2. pdf.

21. Tang L, Yao A, Yuan M, Tang Y, Liu J, Liu X, Qiu R. Transcriptional upregulation of genes involved in photosynthesis of the $\mathrm{Zn} / \mathrm{cd}$ hyperaccumulator Sedum alfredii in response to zinc and cadmium. Chemosphere 2016;164:190-200. https://doi.org/https://doi.org/10.1016/j. chemosphere.2016.08.026.

22. Munekage $\mathrm{Y}$, Hashimoto M, Miyake C, Tomizawa KI, Endo T, Tasaka M, Shikanai T. Cyclic electron flow around photosystem I is essential for photosynthesis. Nature 2004;429:579-582. https://doi.org/https://doi.org/10. 1038/nature025e8.

23. Tikkanen M, Rantala S, Aro EM. Electron flow from PSII to PSI under high light is controlled by PGR5 but not by PSBS. Front Plant Sci 2015;6:521. https://doi.https://doi.org/10.3389/fpls.2015.00521.

24. Sato R, Kawashima R, Trinh MDL, Nakano M, Nagai T, Masuda S. Significance of PGR5-dependent cyclic electron flow for optimizing the rate of ATP synthesis and consumption in Arabidopsis chloroplasts. Photosynth Res 2019;139:359-365. https://doi.org/https://doi.org/10.1007/s11120-018-0533-9.

25. Mikko T, Aro EM. Integrative regulatory network of plant thylakoid energy transduction. Trends Plant Sci 2014;19:11-17. https://doi.org/https://doi.org/ 10.1016/.j.tplants.2013.09.003.

26. Achim $\mathrm{H}$. Role of the plasma membrane $\mathrm{H}^{+}$-ATPase in auxin-induced elongation growth: historical and new aspects. J Plant Res 2003;116:483505. https://doi.org/https://doi.org/10.1007/s10265-003-0110-x.

27. Rober-Kleber N, Albrechtová JT, Fleig S, Huck N, Michalke W, Wagner E, Speth V, Neuhaus G, Fischer-Iglesias C. Plasma membrane $\mathrm{H}^{+}$-ATPase is 
involved in auxin-mediated cell elongation during wheat embryo development. Plant Physiol 2003;131:1302-1312. https://doi.org/https://doi. org/10.1104/pp.013466.

28. Kim YS, Min JK, Kim D, Jung J. A soluble auxin-binding protein, ABP57 purification with anti-bovine serum albumin antibody and characterization of its mechanistic role in the auxin effect on plant plasma membrane $\mathrm{H}^{+}$ATPase. J Biol Chem 2001;276:10730-10736. https://doi.https://doi.org/10. 1074/jbc.M009416200.

29. Xu W, Jia L, Baluška F, Ding G, Shi W, Ye N, Zhang J. PIN2 is required for the adaptation of Arabidopsis roots to alkaline stress by modulating proton secretion. J Exp Bot 2012;63:6105-6114. https://doi.org/https://doi.org/10. 1093/jxb/ers259.

30. Atici Ö, Ağar G, Battal P. Changes in phytohormone contents in chickpeaseeds germinating under lead or zinc stress. Biol Plant 2005;49:215222. https://doi.org/https://doi.org/10.1007/s10535-005-5222-9.

31. Zhang Y, Yan Y, Fu C, Li M, Wang YA. Zinc sulfate spray increases activity of carbohydrate metabolic enzymes and regulates endogenous hormone levels in apple fruit. Sci Hortic 2016;211:363-368. https://doi.org/https://doi. org/10.1016/j.scienta.2016.09.024

32. Wang SY, Yuan SL, Su LT, Lv AM, Zhou P, An Y. Aluminum toxicity in alfalfa (Medicago sativa) is alleviated by exogenous foliar IAA inducing reduction of Al accumulation in cell wall. Environ Exp Bot 2017;139:1-13. https://doi. org/https://doi.org/10.1016/j.envexpbot.2017.03.018.

33. Cakmak I. Possible roles of zinc in protecting plant cells from damage by reactive oxygen species. New Phytol 2000;146:185-205. https://doi.org/ https://doi.org/10.1046/j.1469-8137.2000.00630.x.

34. Fan XY, Zhang J, Li WJ, Peng LW. The NdhV subunit is required to stabilize the chloroplast NADH dehydrogenase-like complex in Arabidopsis. Plant J 2015;82:221-231. https://doi.org/https://doi.org/10.1111/tpj.12807.

35. Alboresi A, Storti M, Morosinotto T. Balancing protection and efficiency in the regulation of photosynthetic electron transport across plant evolution. New Phytol 2019;221:105-109. https://doi.org/https://doi.org/10.1111/nph. 15372.

36. Strand DD, Fisher N, Kram DM. The higher plant plastid complex I (NDH) is a reversible proton pump that increases ATP production by cyclic electron flow around photosystem I. bioRxiv. 2016;049759 https://doi.org /https://doi. org/10.1101/049759.

37. Bui LT, Novi G, Lombardi L, lannuzzi C, Rossi J, Santaniello A, Mensuali A, Corbineau F, Giuntoli B, Perata P, Zaffagnini M, Licausi F. Conservation of ethanol fermentation and its regulation in land plants. J Exp Bot 2019;70: 1815-1827. https://doi.org/https://doi.org/10.1093/jxb/erz052.

38. Wei YL, Lin M, Oliver DJ, Schnable PS. The roles of aldehyde dehydrogenases (ALDHs) in the PDH bypass of Arabidopsis. BMC Biochem 2009;10:7 https://doi.https://doi.org/10.1186/1471-2091-10-7.

39. Danie B, Konrad B, Toplak M, Lahham M, Messenlehner J, Winkler A, Macheroux $P$. The family of berberine bridge enzyme-like enzymes: a treasure-trove of oxidative reactions. Arch Biochem Biophys 2017;632:88103. https://doi.org/https://doi.org/10.1016/j.abb.2017.06.023.

40. Kelsey RG, Westlind DJ. Physiological stress and ethanol accumulation in tree stems and woody tissues at sublethal temperatures from fire. BioScience. 2017; 67:443-451. https://doi.org/https://doi.org/10.1093/biosci/bix037.

41. Petrovova M, Tkadlec J, Dvoracek L, Streitova E, Licha I. NAD(P)H-Hydrate Dehydratase- a metabolic repair enzyme and its role in bacillus subtilis stress adaptation. PLoS One 2014;911:e112590. https://doi.https://doi.org/10. 1371/journal.pone.0112590.

42. An Y, Zhou P, Qiu X, Shi D. Effects of foliar application of organic acids on alleviation of aluminum toxicity in alfalfa. J Plant Nutr Soil Sci, 2014;177(3), 421-430. https://doi.org/https://doi.org/10.1002/jpln.201200445.

43. Sun P, Tian Q. Y, Chen J, Zhang W. H. Aluminium-induced inhibition of root elongation in Arabidopsis is mediated by ethylene and auxin. J Exp Bot, 2010; 61(2), 347-356. https://doi.org/https://doi.org/10.1093/jxb/erp306.

44. Huang W, Zhang SB, Xu JC, Liu T. Plasticity in roles of cyclic electron flow around photosystem I at contrasting temperatures in the chilling-sensitive plant Calotropis gigantea. Environ Exp Bot. 2017;141:145-153. https:// doi. org/https://doi.org/10.1016/j.envexpbot.2017.07.011.

45. Yuan X, Zhang L, Ning N, Wen Y, Dong S, Yin M, Guo M, Wang B, Feng L, Guo P. Photosynthetic physiological response of Radix Isatidis (Isatis indigotica Fort.) seedlings to Nicosulfuron. PLoS One 2014;9:e105310. https:// doi.https://doi.org/10.1371/journal.pone.0105310.

46. Huang W, Tikkanen M, Cai YF, Wang JH, Zhang SB. Chloroplastic ATP synthase optimizes the trade-off between photosynthetic $\mathrm{CO} 2$ assimilation and photoprotection during leaf maturation. BBABioenergetics, 2018;185910: 1067-1074. https://doi.org/https://doi.org/10. 1016/j.bbabio.2018.06.009

47. Yamori W, Makino A, Shikanai T. A physiological role of cyclic electron transport around photosystem I in sustaining photosynthesis under fluctuating light in rice. Sci Rep 2016;6:20147. https://doi.org/https://doi.org/ 10.1038/srep20147.

48. Xia XJ, Wang YJ, Zhou YH, Tao Y, Mao WH, Shi K, Asami T, Chen Z, Yu JQ. Reactive oxygen species are involved in brassinosteroid-induced stress tolerance in cucumber. Plant Physiol. 2009;150:801-814. https://doi. org/ https://doi.org/10.1104/pp.109.138230.

49. Eilers PHC, Peeters JCH. A model for the relationship between light intensity and the rate of photosynthesis in phytoplankton. Ecol Model 1998;42:199215. https://doi.org/https://doi.org/10.1016/0304-3800(88)90057-9.

50. Li P, Weng J, Zhang Q, Yu L, Yao Q, Chang L, Niu Q. Physiological and biochemical responses of Cucumis melo L. Chloroplasts to low-phosphate stress. Front Plant Sci. 2018;9:1525. https://doi.https://doi.org/10.3389/fpls. 2018.01525

51. Zhang G, Liu Y, Ni Y, Meng Z, Lu T, Li T. Exogenous calcium alleviates low night temperature stress on the photosynthetic apparatus of tomato leaves. PLoS One 2014;9:e97322. https://doi.https://doi.org/10.1371/journal.pone. 0097322.

\section{Publisher's Note}

Springer Nature remains neutral with regard to jurisdictional claims in published maps and institutional affiliations.
Ready to submit your research? Choose BMC and benefit from:

- fast, convenient online submission

- thorough peer review by experienced researchers in your field

- rapid publication on acceptance

- support for research data, including large and complex data types

- gold Open Access which fosters wider collaboration and increased citations

- maximum visibility for your research: over $100 \mathrm{M}$ website views per year

At $\mathrm{BMC}$, research is always in progress.

Learn more biomedcentral.com/submissions 